Historic, archived document

Do not assume content reflects current scientific knowledge, policies, or practices. 


\section{HEAT EFFECTS}

ON

\section{LIVING PLANTS}

Robert C. Hare

Southern Forest Experiment Station

Philip A. Briegleb, Director FOREST SERVICE

U.S. Department of Agriculture 



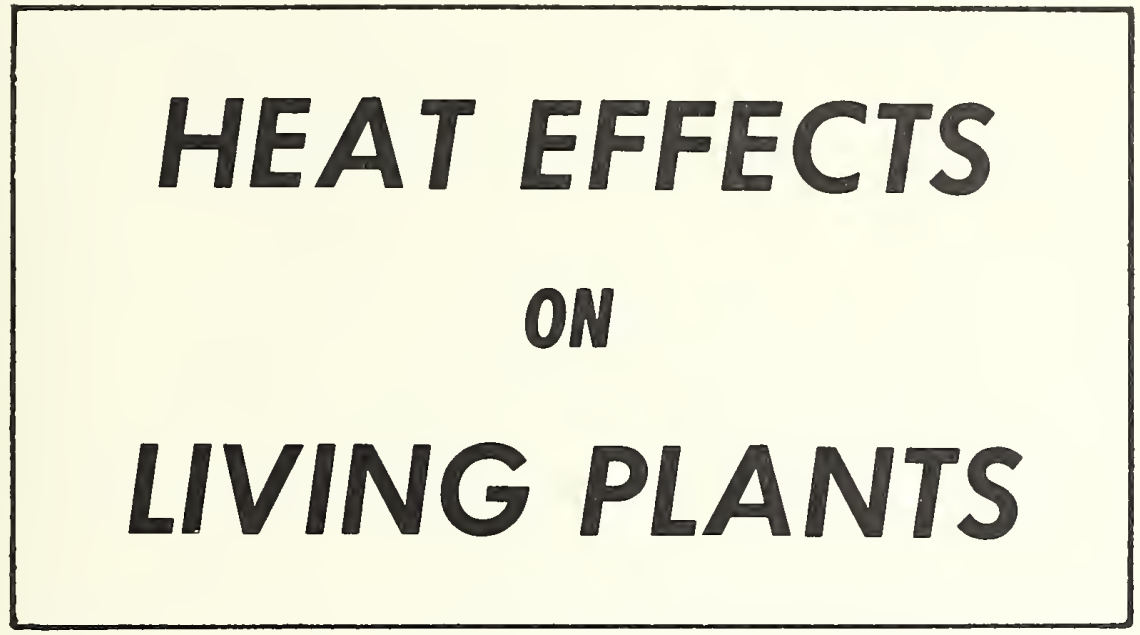

Robert C. Hare

Southern Forest Experiment Station

Philip A. Briegleb, Director

FOREST SERVICE

U.S. Department of Agriculture 



\section{CONTENTS}

INTRODUCTION

TEMPERATURES ENCOUNTERED IN FOREST FIRES . . . 1

In Air . . . . . . . . . . 1

In Soil . . . . . . . . . . . . . . 2

In Plant Tissues . . . . . . . . . . . 2

GENERAL EFFECTS OF HIGH TEMPERATURE . . . . 3

Fire Effects . . . . . . . . . . . . . 3

Insolation Effects $\quad . \quad$. $\quad . \quad . \quad . \quad . \quad . \quad . \quad$. 7

EFFECTS OF FIRE ON SOILS

EFFECTS OF FIRE ON PLANT ASSOCIATIONS . . . . 8

Fire Ecology . . . . . . . . . . 9

Beneficial Fire Effects-Prescribed Burning . . . . 9

LETHAL TEMPERATURES.$\quad$. . . . . . . 11

Seedlings . . . . . . . . . . . . 11

Stems and Roots . . . . . . . . . . 12

Leaves . . . . . . . . . . . 12

Seeds . . . . . . . . . . 12

VARIABLES AFFECTING HEAT INJURY . . . . . 13

Physical Factors in Heat Resistance . . . . . 13

Intermediate Factors in Heat Resistance . . . . 15

Physiological Factors in Heat Resistance . . . . 15

EXPERIMENTAL METHODS, INSTRUMENTATION . . . 18

External Evidence of Heat Injury . . . . . 18

Internal Evidence of Heat Injury . . . . . . 19

Methods of Heat Application . . . . . . . 20

Techniques for Measuring Temperature . . . . 21

SUMMARY OF RESEARCH NEEDS . . . . . . 22

Temperature Measurement During Fires . . . . 22

Thermal Characteristics of Bark . . . . . . 22

Identification of Internal Heat Injury . . . . . 22

Lethal Time-Temperature Curves . . . . . 22

Physiological Effects of High Temperature . . . . $\quad 22$

Importance of Various Factors in Fire Resistance . . . 23

Recovery Processes . . . . . . . . 23

LITERATURE CITED $\quad$. $\quad . \quad$. $\quad$. . . . . 24 


\section{INTRODUCTION}

This review of knowledge concerning the effects of high temperatures on plants was undertaken in preparation for research aimed at determining how forest fires affect physiological processes in woody species. Major subjects discussed include morphological and physiological responses to high temperatures, external and internal factors governing these responses, recognition and assessment of fire damage, and ecological effects of fire, including benefits from prescribed burning. Consideration is given also to techniques for measuring high temperatures outside and inside the plant, and for reproducing these temperatures artificially in controlled experiments. Some of the fire effects reviewed here are not physiological, but a cursory survey of literature on them was included to round out the treatment, since they all constitute ways in which excessive heat influences plants.

A major conclusion from this literature survey is that we know little about the physiological effects of fire. Even such prerequisite information as that on internal temperatures during fires seems completely lacking. Investigations of heat-induced changes in physiological processes like respiration, translocation, and auxin or enzyme reactions should lead to improved ability to appraise wildfire damage, and to produce desired results by prescribed burning. Physiological research may also provide methods for increasing the fire resistance of desirable trees through genetics or chemistry. The closing section of this paper is thus devoted to present research needs in physiology, and to possible experimental approaches.

No geographical limits have been placed on this review; any preponderance of data from the southern United States merely reflects the greater use and occurrence of fire in this region. Other aspects of fire research in the South have been analyzed by Bruce $(36)^{1}$, and Nelson and Bruce (160).

\section{TEMPERATURES ENCOUNTERED IN FOREST FIRES}

The temperatures to which a plant is subjected depend on its distance from the flames as well as on the intensity and duration of the fire. Intensity and duration are determined by such factors as the fuel (type, moisture content, size, spatial distribution) (42), the general slope of the ground, and external atmospheric influences like wind speed and relative humidity.

\section{In Air}

Air temperatures during fires in various types of fuel vary greatly. Convection columns reached $1,100^{\circ}$ F. ${ }^{2} 45$ feet above a pile of burning railroad ties (214). Flame temperature (measured with an optical pyrometer) averaged $1,600^{\circ}$, with a maximum of $2,000^{\circ}$. In a running brush fire the convection column reached $915^{\circ}$ at 15 feet above the ground. In fires in Appalachian hardwoods (161) maximum temperatures near the ground varied from $1,112^{\circ}$ to $1,832^{\circ}$. At 5 feet the maximum was $392^{\circ}$, at 10 feet, $212^{\circ}$. Uggla (209) reported maxima of more than $2,100^{\circ}$ during slash fires in pine and spruce stands in Sweden.

During experimental fires in a longleaf pine stand with a large accumulation of needle litter (8-year rough) maximum temperatures approached $1,600^{\circ}$ (64). Maxima were somewhat higher immediately adjacent to tree trunks $\left(1,560^{\circ}\right)$ than in the open $\left(1,300^{\circ}\right)$. Radiation from heated bark surfaces and induced convection currents close to the boles presumably accounted for the difference. In the open, temperature decreased consistently with height above ground, but next to tree trunks highest readings occurred 3 feet above giound on the lee side.

Both temperature and duration of exposure are greatly influenced by the wind. Headfires develop considerably more heat than backfires because the flames are fanned by the wind to ignite new fuel ahead of the front, more fuel burns per unit of time, and more aerial fuels are consumed. Therefore, headfires usually do more crown damage than backfires. In backfires, where the heat is blown into the burned area, progress of the flame front is very much slower, and parts near the ground are exposed to high temperatures for a longer time.

1 Italic numbers in parentheses refer to Literature Cited, page 24.

" Unless otherwise indicated, all temperatures are in Fahrenheit. 
In South Carolina, Lindenmuth and Byram (127) measured heating at several levels with heavy-gauge thermocouples having approximately the heat capacity of buds of longleaf pine seedlings. The "temperature factor," representing both temperature and its duration, was greatest 5 inches above the ground in both headfires and backfires. Measured in this way, backfires were consistently hotter below 18 inches, and headfires were hotter above this level. The fuel included much grass, which burns with the base of the flames at a higher elevation than in unsupported pine litter. Byram (43) suggests that headfires in grassy fuels may do less damage close to the ground than backfires.

Measured with fine thermocouples, headfires in homogeneous pine litter in southern Mississippi were generally hotter at all levels than backfires (64). Maximum air temperatures adjacent to tree trunks at ground level (for both lee and windward sides of the tree) averaged $1,144^{\circ}$ in headfires versus $974^{\circ}$ in backfires. Peaks were at $1,520^{\circ}$ and $1,325^{\circ}$, respectively. At the 1 -foot level, maxima averaged $1,058^{\circ}$ and $819^{\circ}$ but ranged to $1,460^{\circ}$ for headfires and to $1,240^{\circ}$ for backfires. Headfire maxima showed little change up to 3 feet (average at 3 feet was $1,023^{\circ}$ ), whereas backfire maxima dropped rapidly with height (average at 3 feet was $375^{\circ}$ ). In the open air, away from tree trunks, air maxima at the litter surface were $1,300^{\circ}$ in a backfire, $1,215^{\circ}$ in headfires. At 5 inches the backfire maximum had dropped to $670^{\circ}$, and at 10 inches to $350^{\circ}$, as compared with $1,135^{\circ}$ and $800^{\circ}$, respectively, for headfires. Backfire temperatures continued to drop more rapidly than headfire temperatures with height. Thus in these fuels, backfires may be hotter than headfires, if at all, only at the surface. Radiation from the approaching flame front and slow movement of the front may make backfires more damaging at points close to the ground.

In gallberry-palmetto roughs of Georgia a maximum of $1,600^{\circ}$ was measured in headfires at the 1-foot level, the temperature falling off with height in a sloping curve (56). Backfires at one foot reached only $250^{\circ}$ to $600^{\circ}$, but maintained this level for several minutes. At 4 feet, headfires reached $500^{\circ}$, backfires $125^{\circ}$. Again headfires did not appear to be cooler near the ground, unless within a few inches.
Wind and convection currents also affect heat damage through the so-called chimney effect. Almost invariably bark charring is highest on the leeward side of the trees. As the wind blows the flames around the bole a convection column rises on the protected side, carrying the heat and flames up as in a chimney. This occurs in both headfires and backfires. It is more pronounced in headfires because the leeward fuel has already burned when the flame reaches the windward side in backfires. In the experimental burns mentioned above (64), air maxima averaged $1,330^{\circ}$ at 3 feet above ground on the lee side, and $716^{\circ}$ on the windward side. Backfire maxima averaged $468^{\circ}$ on the lee and $282^{\circ}$ to windward. At one foot and above, leeward maxima were up to 4 times as high as windward maxima, high temperatures were maintained longer, and cambium kill was considerably greater.

\section{In Soil}

During 44 experimental fires in a diversity of natural fuels in longleaf pine stands soil temperatures at a depth of $1 / 8$ - to $1 / 4$-inch reached $274^{\circ}$, but most readings at this depth were less than $175^{\circ}$ (104). Below $1 / 2$ inch there was usually little or no rise. Thus the fires probably had little direct effect on soil or underground plant organs.

Under natural burning conditions in Australia, surface temperatures ranged from $178^{\circ}$ to $416^{\circ}$ (17). A maximum of $153^{\circ}$ was recorded 1 inch below the surface. Beneath a pile of burning slash the soil reached $238^{\circ}$ at 1 inch and $153^{\circ}$ at 3 inches. Dryness favored the penetration of heat into the soil.

The humus layer had a strong insulating effect during a very hot fire in Sweden (209). Temperatures reached $2,100^{\circ}$ in the air, $1,000^{\circ}$ at the litter surface, but only $250^{\circ} 11 / 4$ inches below the surface. In grass fuels in California, maximum temperatures were $250^{\circ}$ at the surface and $180^{\circ}, 165^{\circ}, 145^{\circ}$, and $135^{\circ}$, respectively, at depths of $1,2,3$, and 4 inches (21). With heavy brush fuels soil temperatures ranged about 3 times as high as with grass.

\section{In Plant Tissues}

Published data on internal plant temperatures during forest fires are lacking. Some unpublished records have been obtained of 
cambium temperatures during both actual and simulated forest fires. During natural-fuel burns in the longleaf pine region of Mississippi, maximum cambium temperatures varied from $85^{\circ}$ to $500^{\circ}$ at the 1 -foot level on the leeward side (64). Maximum external temperatures at this position were $550^{\circ}$ to $1,460^{\circ}$. Bark thickness averaged 0.62 inch.

Both pines and hardwoods were heated by igniting an oil-saturated asbestos rope that had been wrapped around the base of the bole (188). Maxima on the bark surface 1 to 2 feet above the rope ranged from 612 to $1,530^{\circ}$, indicating fairly close approximation to a natural forest fire. Cambium temperatures directly beneath the externai measuring points, varied from $80^{\circ}$ to $520^{\circ}$. The average external temperature in 40 tests was $1,054^{\circ}$, the average cambium temperature $155^{\circ}$, and the average bark thickness 0.66 inch. In general, cambium temperature was related more to bark thickness than to maximum external temperature or species.

\section{GENERAL EFFECTS OF HIGH TEMPERATURE}

\section{Fire Effects}

Fire injures trees physically by burning off bark or causing it to slough off later, and by killing leaves, buds, branches, roots, or portions of cambium of the main stem. Loss of growth frequently follows such injuries. If the damage is great enough, such as complete defoliation or girdling of the bole, the tree may die. Even if death is not immediate, decay, insects, or disease may enter through the fire wounds or otherwise attack and ultimately kill the weakened tree. In addition to such physical manifestations of heat injury there may be less obvious effects on the physiology of the plant.

Fire scars.-Wounds may be either open or hidden under the bark, in which case callus may eventually bulge out and split the bark, exposing the sapwood $(121,122)$. Thirty-three years after a fire in a lodgepole pine stand in Alberta, 86 percent of the trees examined had basal fire scars, averaging 4.7 feet in length (163). Of 2,703 felled loblolly pines in Alabama, 16 percent had one or more fire scars (80). Hardwoods in plots burned every fifth year had more fire scars than those in annually burned plots-34 percent vs. 27 percent (170).

Scarring from single fires in the South is usually more serious in hardwood stands than in pines. For various reasons southern pine stands are burned more frequently than hardwoods, so that fuel accumulations in pine types are often too low to support very hot fires. Resin flow in pines also helps prevent the entry of decay; and they have relatively thick bark, though bark thickness may be reduced slightly by repeated fires (145).

Growth loss.-Loss of growth as a result of fire damage varies considerably. For several years following a fire, annual rings in western yellow pine were severely reduced or missing, depending on the amount of defoliation (54). Growth is, of course, slowed by loss of leaves for manufacturing food, but apparently basal fire wounds have little effect on hardwood growth (115). Even severe wounding of yellow-poplar and white oak stems did not decrease diameter growth, although growth of scarlet oak on a poor site was reduced somewhat. Injured trees were not significantly lower in moisture content, ash, nitrogen, or carbohydrates, except that in scarlet oak foliar nitrogen tended to be low in trees with large wounds. Phloem and xylem near fire wounds quickly became oriented in such a direction as to favor passage around the wounds. Thus, translocation of water, minerals, or food was not seriously hampered.

In ponderosa pine a single fire reduced height growth but not diameter growth (156). In comparison with unburned controls, longleaf pine saplings exposed to 5 years of annual burning lost 20 percent in diameter growth and 25 percent in height growth; larger trees were little affected (223). In another study of longleaf pine (146) three annual fires slowed both diameter and height growth, especially in younger trees. According to Wahlenberg (222), a single fire causing heavy defoliation in sapling or pole-sized longleaf commonly results in a loss equivalent to one full year's height growth, the loss being distributed over about 3 years.

In southern Mississippi and western Louisiana, Stone (197) compared the annual radial growth of 1,200 longleaf pines subjected to numerous fires. Decrease during the first year following a fire ranged from 0 to 65 percent of the expected growth. Recovery was rapid and usually complete in two to three years. 
Winter backfires in grass or litter fuels did not affect height or diameter growth of slash pine. Headfires reduced both types of growth, particularly of trees under 12 feet high (89, 149). Heat from backfires did not reach high enough to defoliate the trees.

In slash pine, as in ponderosa and longleaf, height growth seems more sensitive to fire than diameter growth (149). Slash pines up to 7 inches d.b.h. lost height growth where no needle scorch was apparent, whereas diameter growth was not affected even in 3-inch saplings with $1 / 3$ of the crown scorched. (It would be interesting to know what factors reduce height growth in the absence of apparent foliar injury). In trees less than 3 inches d.b.h. diameter growth was lost even without scorching. Crown scorch greater than $1 / 3$ decreased both height and diameter growth of all trees in proportion to degree of scorching. Within three years after injury diameter growth, but not height growth, had returned to normal, except in severely scorched small trees.

A single severe April fire in North Carolina seemed not to retard diameter growth of surviving 30-year-old shortleaf pines, even where crowns had been 100 percent scorched (114).

In the Plains of New Jersey dwarf forests of pitch pine, scrub oak, and blackjack oak may average only 4 to 6 feet in height, though up to 60 years old. Andresen (7) showed that frequent fires are the cause of this dwarfing, and not toxic levels of aluminum, as often suggested. Trees on similar soils, but protected from fire, grew normally.

An anomalous effect on diameter growth may be the development of an enlarged bole near ground level. Such buttressing has been reported in loblolly pine (49), longleaf pine (6), and in hardwoods (206). In pine it is claimed to be a protective reaction (49), although it is not clear whether the increased diameter is due to thicker bark, which would be necessary for increased protection of the cambium. Stone (198) questions the buttressing effect in longleaf pine because he found that fire drastically reduced radial growth in the lower trunk, reducing rather than increasing the taper.

Mortality.-Mortality is a more important type of damage than growth loss, particularly with hardwoods. Immediate appraisal of kill in the Northeast proved unreliable since mortality did not reach a peak until the second year (192, 193, 194). Oaks appeared only scorched after a surface fire, but more than 60 percent of the survivors showed later effects, such as death, open scars, or attacks by insects or fungi. In order to avoid serious losses from delayed effects a conservative policy would be to cut severely all scorched hardwoods as soon as possible after a fire (194).

Of 829 hardwoods on 15 burned plots in New York and New England 65 percent were killed outright by fire, more than half of these being in the 1- and 2-inch d.b.h. classes (193). Only 4 percent of the remaining trees escaped basal scorching. After 6 years about one-third of the surviving scorched trees had recovered, a third had died, and the remainder showed fire scars and insect and fungal attacks. White pine followed a similar course of delayed mortality and disease and insect infestation.

With southern pines there have been many attempts to predict fire mortality, with varying degrees of error. The extremes of damage are easily recognized but recovery from moderate wounding is affected by many variables. In severely burned loblolly and shortleaf pine (151), percent of crown scorch and extent of cambium kill at groundline were better mortality indicators than height of bark charring, presence of bark beetles, or pitch bleeding. Needle scorch was the best indicator, especially if combined with " 100 percent" cambium kill, i.e., cambium found dead at 4 sampled points around the circumference. Any lesser degree of cambium kill had little effect, and even with "100 percent" kill less than 50 percent crown scorch was seldom fatal. About 11 percent of the injured trees died within two years.

Degree of crown scorch seems to be the best indicator of mortality in longleaf and slash pines also (199). In a severe March headfire even 100 percent needle scorch caused no mortality, presumably because of the low initial temperature $\left(45^{\circ}\right)$; where needles were actually consumed many trees were killed. Ninety percent of the pines died when half the needles or more were consumed, 40 percent when less than half. Height of bark char in relation to tree height was also correlated with mortality. Few trees with less than 60 percent 
stem char died, whereas 90 percent of those with over 80 percent char succumbed. Species or diameter did not seem to affect results.

Ferguson (68) states that the pines most likely to die after a fire are first, those with all foliage consumed, second, those with complete crown scorch plus severe bark burn, and third, those with complete crown scorch or severe basal damage alone. Of 975 fire-damaged trees, 15 percent died. Summer fires were twice as damaging as winter fires. McCulley (149) found that less than 70 percent crown scorch is seldom fatal to slash pine over 5 feet tall, but that if part of the crown is consumed mortality is much greater. He developed a prediction equation for slash pine mortality based on d.b.h., percent foliage scorched, and percent foliage consumed.

Most healthy loblolly pines survived a 5-acre hot spot in a prescribed summer burn in Virginia (4), despite severe needle kill. Only the smaller trees ( 87 percent scorch) were seriously affected (48 percent mortality in trees 5 inches d.b.h. vs. 2 percent in 8 -inch or larger diameters).

Mortality in 30- to 40-year-old ponderosa pines was correlated with crown scorch (143). All trees with scorch exceeding 90 percent died within two years, but little mortality occurred with less than 80 percent crown scorch. Bark scorch caused no mortality in trees of more than 6 inches d.b.h. unless accompanied by more than 80 percent crown scorch. On smaller trees mortality was correlated with bark scorch. Survival of fire-damaged ponderosa pine is also discussed by Herman (100).

On all reports thus far cited, mortality rates were determined from selected injured trees, hence the apparently high losses for large trees. Bruce (34) summarized data on all exposed trees on 479 plots in 188 wildfires, a total of 69,000 southern pines. No deaths were recorded in trees larger than 9 inches d.b.h.; 10 percent died in the 6 -inch class, and 40 percent were lost from the 1-inch class. Among seedlings between $1 / 2$ and 2 feet in height, the fires killed 98 percent of the slash and loblolly, and 48 percent of the longleaf. Loblolly was generally most susceptible, longleaf least. Contrasted to the relatively low average mortality of southern pines in most fires is the killing of nearly all trees by very severe fires (24).
According to Wahlenberg (222) it is necessary to wait until the end of the growing season following the fire to predict mortality in longleaf pine. Even the apparent intensity of a fire can be misleading. Six months after a slow fire in a Texas loblolly-shortleaf stand, there was no apparent damage to crowns or trunks. But 12 months later many trees were dying, and eventually about 10 percent succumbed. Enough fuel had accumulated at the base of large trees to permit the fire to burn deeply into the bark in the lower foot of the trunk (71).

Seedlings of most species, being tender and succulent, are very suspectible to fire. Longleaf pine in the grass stage is an exception because of certain adaptations, including a stout taproot, thick bark, and protection of the growing tip by heavy foliage and a position below the zone of flames. When height growth is beginning longleaf is more vulnerable than in the grass stage, but once well out of the grass it excels all other southern pines in fire resistance (222). Bruce (33) observed the effects of winter fires on longleaf seedlings. All vigorous yearling seedlings and about $3 / 4$ of those in fair vigor survived. Mortality was correlated with groundline diameter, all seedlings 0.20 inch or more in diameter surviving. The tolerance of seedlings of other pine species to artificial heat has been found $(12,213)$ to vary more among individual plants than among species.

Root damage from fire has received little attention. Heat penetration in moist soils is very limited; dry soils provide less protection (17). Heyward (101) reported that a very hot fire in Georgia killed all pine feeding roots to a depth of one inch. Even though the greatest concentration of pine roots is usually in the top inch, he believed that little harm ressults even from such exceptional fires, since the roots were quickly regenerated.

In dried swamps the high organic matter may allow ground fires to burn, consuming even large tree roots and killing the trees (101). In Alaska, on sites where roots are shallow and humus deep, ground fires may burn off roots up to 9 inches in diameter (139).

Insects and decay.-Following fire, insects and decay are responsible for much loss of timber (95). Stickel (191) points out that in appraising fire damage little attention is paid 
to trees with slight basal scorching if they remain green. But more than half of the firescorched hardwoods examined six months after a fire were infested with beetles. It has been estimated that 97 percent of basal wounds are caused by fire (99) and that 90 percent of butt rots enter through these wounds (93).

In the Northeast, insects attack hardwoods within a year after fire injury, but fungal decay may not be evident until the third year or even later $(193,194)$. Of 30 species of wood-rotting fungi identified in hardwoods of the Mississippi Delta, 5 were responsible for half the decay. Within 4 years the bark had sloughed off most wounds and decay fungi had become well established. Wounds less than 2 inches wide led to no serious decay $(206,207)$.

Hepting and Blaisdell (97) reported that sweetgum and persimmon were resistant to decay infection through fire wounds. This resistance was ascribed to the formation on the wound surface of a hard zone of sapwood cells, heavily infiltrated with gum. Blocks of this tissue, inoculated with decay fungi and incubated in closed tubes, were able to resist decay for a year. Copious flows of resin tend to keep fungi out of wounds in pine. Intense heat per se also promotes resin flow (personal observation). Resin has no toxic effect but prevents the entrance of fungi by its waterproofing action (217).

Because fire wounds do not lead to decay as frequently in southern pines as in hardwoods, a scar, by itself, is a very uncertain indication of rot. In contrast to the many species of fungi which cause decay in hardwoods and enter mainly through fire wounds, most rot in shortleaf and loblolly pines in Arkansas and Texas was red heart (Fomes pini), which usually entered through branch stubs (98). Polyporus schweinitzii caused some cull in the butts, gaining entrance largely through fire wounds. Lodgepole pine seems less resistant to infection than southern pines; 45 percent of fire-scarred trees in Alberta had infected wounds (163). However, there was considerable resistance to rot, since 33 years after the fire the wood evidenced no advanced decay, only firm red stain.

Disease.-Diseases (other than decays) may be influenced by fire, both positively and negatively. Fire aids in controlling the brown-spot needle blight of longleaf pine seedlings, but brown spot increases fire mortality of the seedlings by decreasing their vigor and by adding diseased needles to the fuel (35).

The fusiform rust disease on slash pine is also influenced by fire. Siggers (185) prescribeburned in an attempt to reduce rust infection, primarily by killing infected branches. However, the end result was increased infection, presumably because the fires stimulated susceptible new growth in early spring when weather was favorable to spore germination and growth, and when production of sporidia was at a peak. The effect of early spring growth on rust susceptibility is also shown where slash pine is cultivated and fertilized $(14,27)$.

Like brown spot, fusiform rust infection increases vulnerability of the tree to fire. The disease not only reduces plant vigor, but also causes pitch to flow on and below the canker which adds fuel (14).

Physiological effects.-Fire effects on plant tissues are not well understood. Little is known about effects of near-lethal high temperatures on plant functions, or, in fact, on how heat kills cells. Belehradek lists 5 general theories, any or all of which may explain the mechanism of heat injury to protoplasm. These are: coagulation, heat destruction of enzymes, asphyxiation, intoxication, and lipoid liberation.

Coagulation of the proteins in protoplasm is the oldest and most widely accepted theory (20). This process seems to progress from an increase in permeability to a visible coagulation of the protoplast (39). Two common objections are that proteins usually require higher than lethal temperatures for coagulation, and that coagulative changes in the beginning are reversible in protoplasm but irreversible in proteins.

Heilbrunn (94) advances the idea that coagulation depends primarily on the action of heat on fats and lipoids which are emulsified in all living matter. These fats are easily liquefied at lethal temperatures and their liquefaction, or solution, generally results in coagulation of the protoplasm. Small quantities of fat solvents such as ether promote heat coagulation of both plant and animal protoplasm. Like heat, ether in dilute solution increases the 
fluidity of protoplasm, whereas at slightly higher concentrations it causes coagulation. In both animals and plants there seems to be a correlation between lethal temperatures and fat melting points, the less heat-resistant organisms having endogenous fats with lower melting points.

Fire may influence some physiological functions indirectly. In hardwoods basal wounds had little effect on translocation, since nearby conductive elements became quickly reoriented to maintain transport around the wound (115). In pines, defoliation by fire increased the moisture content of the upper stems (179) and appeared thereby to lessen the attractiveness of the trees to beetles immediately after the fire. Defoliated trees averaged 91 percent moisture content above the base, as compared to 64 percent in normal trees. Apparently, transpiration in the foliated trees reduced moisture content in the upper stem. Another indirect physiological effect of severe fires may be to reduce the incidence of mycorrhizae, known to be important in tree nutrition, on roots in the upper soil layer (240).

Loss of food production may not be the only factor retarding the growth of fire-defoliated trees. Oland (164) quotes Murneek to the effect that prior to natural abscission some 40 to 50 percent of the total nitrogen of the leaves is reabsorbed by the tree. This nitrogen is an important source of reserves for use the following season. Thus premature defoliation, at least of deciduous trees, may result in a loss of nitrogen to the plant.

Other possible physiological effects of fire on such life processes as respiration and enzyme action have not been reported.

\section{Insolation Effects}

Not all heat injury is caused by fire. The direct heat of the sun occasionally wounds plants, e.g., sunscald of tree trunks in winter and the "white spot" lesions of tree seedlings at groundline (134). The latter effect is increased by anything which raises the soil surface temperature, such as dryness, duff, and litter. The temperature in a sawdust mulch may be as much as $17^{\circ}$ higher than in bare soil (150). Surface soil temperatures up to $160^{\circ}$ in the sun were recorded by Baker (12).
Conifer seedlings were killed at these temperatures, but were able to survive surface temperatures of $140^{\circ}$ to $150^{\circ}$ with little injury, because the plants were generally $15^{\circ}$ to $20^{\circ}$ cooler than the soil surface.

When insolation raises cambium temperatures, less heat is required from a fire to bring the tissue to a lethal level. Eggert (60) measured over $80^{\circ}$ in the cambium of peach trees on the south side while cambium on the north side and air temperature were below $32^{\circ}$; Bergstrom (22) reports a difference of $13^{\circ}$. A fire under these conditions would be expected to cause more injury on the south side, other factors being equal. Internal leaf temperatures in sunlight may exceed air temperature by $25^{\circ}$ or more $(8,39,51,119)$.

\section{EFFECTS OF FIRE ON SOILS}

Although fire effects on soil as such are beyond the scope of this review, soil changes by heat do affect the growth of plants, hence constitute an indirect fire effect.

Probably because many factors influence the results, authorities differ as to whether fire is detrimental to forest soils. On some points there is general agreement. The ash deposit from a fire increases available phosphorus, potassium, calcium, and magnesium $(2,11,40$, $74,102,106,139,209,218)$. The alkaline ash decreases soil acidity, thereby stimulating nitrification $(5,13,15,200,239)$. Thus soil is generally improved chemically by fire. While consumption of organic matter may decrease total nitrogen in the upper inch $(5,11,15,74)$, the sharp increase in nitrification is reflected in more luxuriant growth of vegetation, particularly grasses and herbs (13). This fact has given to the southern stockman his strongest argument for frequent burning of forest lands. Most forest trees do not seem to be significantly affected by chemical soil changes brought about by fire (200), but growth of seedlings may be stimulated. In a greenhouse study slash pine seedlings grew better on burned-over than on unburned soil (221); and growth of loblolly pine seedlings in Louisiana was much better for the first three years on plots where hardwood slash had been burned than in an unburned clearing (9). Phosphorus, potassium, and magnesium were all much higher on burned plots, and remained higher for at least 
two years. In Alaska forest soils are said to be benefited by fire, both chemically and physically $(138,139)$.

Ahlgren (2) found that, while soil nutrients were at maximum right after fire, they remained high up to 5 years. Many herbaceous species grew rapidly and displayed marked lushness in size, color, and leaf thickness the first few years (especially the first year) after a fire. Sunflower and oats grown in a greenhouse on burned-over field soils were heavier and more vigorous than those on similar soils that had not been burned over.

Wahlenberg (221) reports that 10 years of protection from fire improved the physical but not the chemical properties of soil from the longleaf pine region. By removing litter and exposing soil to rain, fire can reduce porosity and infiltration rates. Protection from fire soon changes the $A_{1}$ horizon from a dense structure to one that is easily penetrable and porous (103). This effect is ascribed both to the puddling effect of rain and to the action of soil faunas which are greatly reduced in frequently burned-over soils (107). In the Northwest soil bacteria and actinomycetes were found to increase after severe burning (239), but fungi decreased

Sometimes organic matter is increased by burning, owing to stimulation of grass growth and incorporation of roots into the soil. After 8 years of annual grass fires, Mississippi soils had 60 percent more organic matter and 50 percent more nitrogen than similar soils in unburned areas. Forage growth was doubled and soil moisture was not decreased (86).

Alway and Rost (5) likewise found no effect on moisture equivalent, but Austin and Baisinger (11) report lower waterholding capacity just after a fire. An immediate effect may be to reduce soil moisture near the surface, but by removal of shallow-rooted plants and formation of loose mulch fire may also increase soil moisture (105).

Soil texture and structure were not appreciably altered by fire in Alaska, since changes require fusion or baking of mineral particles into larger units, which rarely occurred (139). In most undisturbed mineral soils the low organic content was not conducive to aggregate formation so burning had little effect on soil aggregates.
In some western soils fire seems to increase porosity. Brush burning markedly improved permeability of surface layers, degree of aggregation, and infiltration rates (181). In the ponderosa pine region both percolation rate and macroscopic pore volume were increased (201); the fire was moderate and no incorporated humus was consumed, but the effect may have partially resulted from the burning of dead roots a few inches into the soil. Improved aggregation resulting from the release of basic ash material may also have contributed to the increased volume of macroscopic pores.

Bruce (31) found no significant difference between soils of south Mississippi that had not burned for 13 years and those burned over 3 times in the interval, and Heyward (102) concludes that fire neither definitely harms nor benefits soils of the longleaf pine region.

\section{EFFECTS OF FIRE ON PLANT ASSOCIATIONS}

Fire profoundly influences the flora and fauna of a community. The changes in plant ecology depend on such factors as the intensity and frequency of the burns, how many of each species survive, and the capacity of each species to regenerate. Chemical and physical changes in the soil, and exposure to erosion, may also influence the end result. Benefits from prescribed fires, such as release of pines from hardwood competition, promotion of grass for grazing, and improving conditions for wildlife, all depend on ecological changes brought about by fire.

Most ecologists recognize the existence of a fire subclimax, in which certain timber types, notably pines, owe their existence to periodic fires that prevent taking-over by the climax type. Where the climax type is less desirable man may use fire to maintain the subclimax stage. Little and Moore (130) cite references which indicate that fire may have had an important role in maintaining such types as Douglas-fir, paper birch, and various pines ( pitch, shortleaf, longleaf, loblolly, eastern and western white, lodgepole, and ponderosa). Slash pine should no doubt be included also. The frequency of burning makes fire a major ecological factor in southern pine forests. Garren (81) states that longleaf pine, and possibly scrub oak, require occasional winter fires for their survival, although annual burning is detrimental. 


\section{Fire Ecology}

Two principal grasses, Curtis dropseed and pineland threeawn, may make up half the herbaceous ground cover in the flatwoods of Georgia, since they are adapted to survival by having their meristems 1.5 inches underground (125). In the western portion of the longleaf belt species of Andropogon (bluestems) usually predominate (222). These grasses are important for maintaining structure and organic matter in the soil, and for furnishing fuel. Like longleaf pine, they are well adapted to fire. The "fire-followers" include a large number of species abundant mainly the first year after fire. Most of the forbs in this group are composites and various legumes (110). Ahlgren (2) lists a number of species which he found only on burned sites.

The fire succession pattern in ungrazed upland southern pine forests is forbs-to-perennialgrasses-to-perennial-woody-species a n d depends on the seeding and sprouting habits of the species (110). In the first growing season after burning, the cover of forbs increased and grass and shrubs decreased. After 21/2 growing seasons grass recovered completely, and sprout growth more than replaced hardwood cover under 6 feet. Burning of Ozark hardwoods increased both the number of species and the number of individual plants of most species of grasses, forbs, and mosses (170).

In northeastern Minnesota jack pine, black spruce, quaking aspen, and paper birch reproduced vigorously on burned-over land (1). Seedbed conditions were generally improved except where burning was slight. Similar effects are reported from Alaska (138, 139), where climax stands of white and black spruce are being replaced by shorter-lived hardwoods (paper birch, quaking aspen, balsam poplar) as a result of fires, largely man-made. These hardwoods are able to invade fire-killed areas by virtue of their prolific sprouting and small seed, easily dispersed by wind. The semiserotinous cones of black spruce, however, are opened by fire, resulting in pure, even-aged stands of this species in some areas following fire.

In boreal forests fire may raise soil temperatures by burning off the heavy layer of insulating duff, by blackening from charcoal, and by removing foliar shade, thus increasing ab- sorption of solar radiation. The result is a downward retreat of the permafrost, which may greatly stimulate later tree growth (138).

On upland sites in New Jersey fire eliminated or greatly reduced shade-tolerant species and those reproducing by seed (29). Hemlock, beech, birch, and white pine were replaced by intolerant sprouting species like white, scarlet, and black oak, and pitch pine.

After a fire in California killed all aboveground plant parts, manzanita, gooseberry, and deerbrush (173) took over. Seeds of these firetype species are very heat resistant, surviving for 20 minutes or more in boiling water.

Fire exclusion in areas previously subject to periodic fires also has profound ecological effects. In northern Arizona (53) and on the Pacific slope $(230,234)$, the forests up until the present century were open and parklike. As a result of overgrazing and fire protection, a dense understory has developed, grass has disappeared, and erosion increased. Competition for moisture seems to have enhanced susceptibility to bark-beetle attack. Prescribed fires have been suggested to prevent stagnation and reduce fuel hazard. Similar results in some portions of the longleaf-slash pine belt following complete exclusion of fire led to the present acceptance of prescribed burning.

\section{Beneficial Fire Effects-Prescribed Burning}

The use of fire for various silvicultural purposes, called prescribed burning, was approved by the U. S. Forest Service about 1942, some 13 years after the Southern Forest Experiment Station had initiated studies on the effects of fire on longleaf pine (92). The concept of prescribed burning has been explained by likening the forest manager to a physician who must examine his patient, analyze the findings, and prescribe what, in his opinion, is the remedy (52). It has been defined as: "Skillful application of natural fuels under conditions of weather, fuel moisture, soil moisture, etc., that will allow confinement of the fire to a predetermined area and at the same time will produce the intensity of heat and rate of spread required to accomplish certain planned benefits. . . Its objective is to employ fire scientifically to realize maximum net benefits at minimum damage and acceptable cost." (212). Most or all of the benefits of prescribed burning 
could be obtained by other means, but the advantages of fire is its low cost (70).

In the South fire is frequently employed for seedbed preparation, control of brown-spot disease, release of longleaf seedlings to promote height growth, control of brush competition, reduction of hazardous fuel, and preparation for planting $(23,24,25,28,37,48,69,70)$. Stoddard (192) discusses uses of fire in wildlife management. Fire is also widely employed for improvement of grazing, often to the detriment of the forest (92). As has been noted, either complete exclusion or too frequent burning may be undesirable (57).

Control of brown-spot disease (Scirrhia acicola) on longleaf pine seedlings is one of the most important uses of fire in the South. Seedlings annually defoliated by this disease do not make height growth and eventually succumb. Wakeley (224) states that, to control this disease, "Prescribed burns should be thorough enough to reach practically all infected seedlings, and hot enough to brown, though preferably not hot enough to consume, all needles as high up as infection extends on the seedlings." Verrall (216) has shown that temperatures lethal to leaf tissue are also lethal to the fungus, even though not hot enough to consume or char the needles.

Burns properly made before infection has sapped vitality will greatly reduce the disease without killing the plants. By reducing the number of spores available to infect new needles the following spring, the burns permit seedlings to retain a full crown of healthy needles (32). Fire is an effective preventive because brown-spot spores under usual conditions are disseminated in appreciable numbers only for short distances. As annual defoliation by either fire or disease prevents height growth (224), Siggers recommends burning at three-year intervals (184). Wakeley and Muntz (225) compared 11-year-old longleaf pines on a plot burned twice with unburned controls of the same age. On burned plots 64 percent of the seedlings were above $41 / 2$ feet tall, as compared to only 22 percent on the unburned plots. At the time of the first burn brown spot had killed 37 percent of the foliage; the unburned stand continued to be heavily infected.

Because it is large and firmly attached to its wing, longleaf seed will not easily sift through vegetative ground cover. It germinates promptly and may do so precociously if temporarily prevented from reaching mineral soil. Burning in advance of seedfall is therefore common practice in longleaf silviculture.

Prescribed burns are frequently made in the South to control undesirable hardwoods, since these are generally more vulnerable to fire than the pines. Ferguson $(69,70)$, in Texas, reports temporary control of hardwoods less than 1.5 inches d.b.h. and substantial control of larger ones by single headfires in summer. Successive burns at 1 - to 5 -year intervals can check competing hardwoods at low cost. One burn may suffice to improve seedbeds. Growing-season headfires are generally most effective.

Prescribed burning has a definite place in the management of even-aged loblolly pine on the Coastal Plain $(136,137)$. An initial dormant season fire to reduce rough is followed by three annual light summer fires to kill hardwoods.

Little (128) reports successful applications of fire in the Northeast. In the pine-oak forests of southern New Jersey fire is necessary to maintain or create the subclimax pine stage $(129,130)$. To completely kill small hardwoods, prescribed burns must be started as soon as the pines are large enough, and repeated every 5 years. LeBarron (124) recommends burning to maintain and regenerate timber types in northeastern Washington. As mentioned above, Weaver (230, 231, 232, 233, 234) makes a strong case for prescribed burning in the ponderosa pine forests of the Pacific Slope, both to thin young stands and to control fuel accumulation.

Morris and Mowat (156), in a study of one of Weaver's burns, found that competition on potential crop trees (selected individuals) had been reduced from 2,410 trees to 895 trees per acre. Forty-six percent of the crown was scorched, and 20 percent of the trees developed fire scars, but in 6 years the crop trees grew 36 percent more in diameter and 7 percent more in height than those on unburned plots. Cause of the accelerated growth in excess of benefits from thinning is unknown, but improved soil characteristics may have contributed. They conclude that fire may be an effective thinning teoi in ponderosa stands under the right conditions. Decay following fire is not a problem 
with this species since wounds seldom become infected.

In northern Michigan, prescribed burning promotes regeneration. of jack pine following harvest of mature stands (18). Temperatures of over $122^{\circ}$ are needed to melt the resin which seals the cone scales together; without fire the seeds remain bound in the cone indefinitely.

According to Uggla (210) fire is being used to an increasing extent in silviculture in northern Sweden. Low temperatures inhibit chemical weathering and soil organism activity which normally promote incorporation of humus into mineral soil. Controlled burning when soil is not too dry is the most efficient method of activating the humus, and of reducing the labor of planting and sowing on such land. On this basis and others, Lutz (139) believes that prescribed burning may also have a place in Alaska.

\section{LETHAL TEMPERATURES}

Much of the research on heat tolerance and lethal temperatures in plants has been in relation to insolation damage, but the data should be applicable to fire effects. The external temperature which may be lethal for a given plant tissue depends on many factors-the initial temperature of the tissue, insulating qualities of dead tissue such as bark which separates the living cells from the heat source, physiological condition of the protoplasm, and length of exposure.

The relationship between time and temperature is exponential (within the biokinetic, or "living temperature" zone), so that as the temperature is raised the critical time moves from infinity slowly, then approaches zero very rapidly. Thus a fairly high temperature may cause no apparent injury during comparatively long exposures, whereas a few degrees higher will kill in a brief time. Baker (12) explained this phenomenon on the basis that coagulation of the protoplasm causing death is an exothermic process, causing a kind of chain reaction like an explosion. Therefore, its rate does not conform to the van't Hoff-Arrhenius law that the speed of chemical reaction is doubled with every $10^{\circ} \mathrm{C}$. rise in temperature. The effect of temperature on reaction time is called the "temperature coefficient" or "Q" value. When the reaction speed is doubled with a $10^{\circ} \mathrm{C}$. rise in temperature, the coefficient is 2 for $10^{\circ}$, or $\mathrm{Q}_{10}=2$.

Lorenz (134) obtained $Q_{11}$ values between 3.6 and 360 in 5 tree species. These unusually high coefficients are also associated with the coagulation of proteins, a fact considered by many to lend support to the coagulation theory of heat injury. However, certain other chemical reactions yield a similarly high temperature coefficient, e.g., the action of hot water on starch grains, with a $Q_{10}$ between 57 and 83,900 (20).

It is apparent from the above discussion that the term "lethal temperature" has little meaning unless the time factor is also indicated. The time required for killing bacteria by heat increased in a geometrical progression as the temperature was lowered arithmetically (26).

According to a number of workers the thermal death point at the cellular level for average mesophytic plants lies between $122^{\circ}$ and $131^{\circ}$ F.; $140^{\circ}$ is frequently given as lethal for the plant as a whole. Baker (12) includes a table on the influence of high temperatures on different plants, compiled from the data of a number of investigators. Minimum lethal temperatures for some 20 species varied from $113^{\circ}$ to $139^{\circ}$. Only cacti could survive over $140^{\circ}$

\section{Seedlings}

Seedlings have been used most frequently in studying lethal temperatures.

Baker (12), Lorenz (134), and Shirley (183) investigated the lethal temperature-time curves of tree tissues by heating seedlings in a water bath. Baker studied stem injury in conifers by heating the tops only, the roots being protected in soil or water. Monterey pine was killed in 2 minutes at $130^{\circ}$ or in 5 minutes at $125^{\circ}$. Fifteen minutes at $120^{\circ}$ caused little injury. Lorenz used a neutral red stain to identify living cortical parenchyma cells of 5 tree species after heat treatment. Thirty minutes at $135^{\circ}$ or 1 minute at $152^{\circ}$ was lethal, with no marked difference between species. His "lethal temperatures" were much higher than Baker's, because the two workers were measuring different things. Even though the stain indicated that cells were still alive after exposure to $135^{\circ}$ or more, it is doubtful if a plant so treated 
would survive if planted out. Shirley, working with 4 species of conifers, found that heat tolerance increased with age and mass and that tops were more resistant than roots. The external killing temperature was approximately the same for all species.

Dry heat gave results similar to those obtained in water baths. Baker (12) measured both internal and external stem temperatures of several conifers planted in soil and exposed to artificial radiant heat plus sunshine. Seedlings were killed quickly at $131^{\circ}$ but withstood a few degrees lower for some time. Although no specific differences were found in internal lethal temperatures, species varied somewhat in their tolerance to external heat. Tolerance increased with age but not on a cellular level (12). Seedlings of western conifers were killed when the tops were exposed to $141^{\circ}$ for 1 minute (16). Resistance to hot sand sprinkled over the tops of 4 species of conifer seedlings increased with age, presumably a result of increased lignification (178). Temperatures up to $120^{\circ}$ caused little injury. Above this temperature heat tolerance varied with species, depending on anatomical and transpirational factors.

Ursic (213) heated entire loblolly pine seedlings by placing an electric light in a bundle of seedlings and moist moss. He concluded that seedlings from bales that have been heated to over $122^{\circ}$, even for a short time, should not be planted. Two hours at $130^{\circ}$ was lethal.

\section{Stems and Roots}

Stems and roots of mature plants have apparently received little study in regard to lethal temperatures. Ursic (213) immersed roots of loblolly pine seedlings in hot water; $129^{\circ}$ for 5 minutes was generally lethal, as was $122^{\circ}$ for 30 minutes, or $118^{\circ}$ for 2 hours. Tolerance of individual seedlings varied considerably. In a similar study, $125^{\circ}$ for 17 minutes was lethal for both slash pine and sand pine (82), while $120^{\circ}$ was mostly lethal to sand pine but only slightly so to slash. Neither species was affected by $116^{\circ}$ for 25 minutes.

\section{Leares}

Leaves, being thin and unprotected, are easily killed by fire. Nelson (159) immersed needles of southern pines in hot water, and observed yellowing as a symptom of death. Average lethal temperatures for the 3 species were $147^{\circ}$ for 3 seconds, $142^{\circ}$ for 5 seconds, $140^{\circ}$ for 31 seconds, and $126^{\circ}$ for 11 minutes. Species differences were small.

Konis (119), Kurtz (120), and MacDougal (144) measured the internal temperatures of various xerophytic plants under intense insolation. Cactus continued growing even when the internal temperature reached $137^{\circ}$, and it could tolerate $144^{\circ}$ without injury $(120,144)$. The mechanism permitting such heat tolerance is not known, but Konis explains it on the basis of dehydration of the protoplasm. During the warm season in Palestine leaves of heat-resistant plants contain relatively small amounts of water and have consequently high osmotic values. Plants with the highest osmotic values are generally the most heat-resistant, and vice versa. Younger leaves have lower heat resistance and lower osmotic values. Konis placed leaves of several species of maquis plants in blackened bottles in the sunshine. The lethal temperature varied between species ( 127 to $138^{\circ}$ ), but was always several degrees higher than the maximum observed in nature. Thus the plants should never be damaged by extreme solar heat alone, although desiccation plus high temperatures may cause injury. Young leaves, more sensitive to heat, are not produced in the dry season.

\section{Seeds}

Seeds are apt to be the most heat-resistant stage in the life cycle of the plant. Frequently the embryo is protected by a tough seed coat and the seed itself may be insulated by a hard woody fruit. If it becomes buried under even a shallow layer of earth, it is further protected from fire.

Fire promotes the germination of many Australian tree seeds by drying up and cracking open the fruit (17). Dry seeds of several native species withstood $230^{\circ}$ for 4 hours. In water, soft seeds were killed in 5 minutes at $140^{\circ}$ to $180^{\circ}$, but some hard seeds withstood 70 minutes in boiling water.

Carmichael (44) also found that heat resistance of seeds was inversely correlated with moisture content. At 10 percent relative humidity red pine, jack pine, and black spruce 
seeds were scarcely injured by $180^{\circ}$ for 70 hours. At 20 percent relative humidity, 50 hours was the limit, and at 30 percent more than 10 hours greatly reduced germination. Temperatures lethal to the seeds of 7 weed species from 5 families ranged from $185^{\circ}$ to $220^{\circ}$ with 15 minutes of exposure (112). Percent of germination diminished rapidly as the lethal point for all seeds was neared, indicating that proteins may have been coagulated or enzymes inactivated at these temperatures. According to Sampson (180) most dry seeds are killed by 5 minutes' exposure at $250^{\circ}$ to $300^{\circ}$.

In contrast to the low heat resistance of most moist seeds, ceanothus seeds survived 25 minutes in boiling water (173).

Beaufait (18) found that jack pine seeds are extremely heat resistant; when cones containing seed were heated to $900^{\circ}$ for 30 seconds there was no adverse effect on germination, but 60 seconds at this temperature ignited the cones and was lethal to the seeds. Three minutes at $700^{\circ}$ was required to kill the seeds, cones being ashed under this treatment. As prescribed fires do not normally ash the cones of standing trees, Beaufait concludes that they do not markedly affect seed viability. When seeds unprotected by cone scales were subjected to temperatures up to $1,000^{\circ}$, viability did not decrease significantly intil the wings ashed and the seed coats cracked. Lethal exposures for $700^{\circ}$ ranged between 10 and 15 seconds; for $1,000^{\circ}$ between 0 and 5 seconds.

\section{VARIABLES AFFECTING HEAT INJURY}

Temperature and its duration, the two principal factors outside of the plant that control heat injury, have already been discussed. Wind, as it affects both of these factors, has likewise been mentioned. A number of internal variables also influence fire resistance.

\section{Physical Factors in Heat Resistance}

Initial temperatures and season.-Byram $(41,43)$ emphasizes the importance of initial tissue temperature on fire resistance. If $140^{\circ}$ is lethal, plants at $50^{\circ}$ can endure twice as much heat as those at $95^{\circ}$. The difference in initial temperature is probably the most important reason why greater damage results from summer than from winter fires, particu- larly with evergreen species. Thus Cary (45) states that whereas summer fires often kill large trees and seriously reduce growth, dormant-season burns tend to cause little damage. More trees died in loblolly-shortleaf plantings burned in August than in those burned in January (110). In east Texas summer fires killed twice as many pines as winter fires (68), and headfires in summer were most effective in controlling hardwoods (69).

Direct radiation from the sun may increase plant temperature above that of the air and thus accentuate fire damage, as already mentioned. Another factor with deciduous plants is that they have no foliage to be injured or to provide aerial fuel during the dormant season.

Transpiration, thermal emissivity.-Theoretically transpiration should cool the leaf by removing the latent heat of vaporization, but the practical importance of this process has long been debated. Shirley (183) found the heat resistance of conifer seedlings to be higher in air than in water, and highest in dry air. This difference he ascribed to the cooling effect of transpiration. However, transpiration in loblolly pine seems to be more a function of available soil water and insolation than of atmospheric humidity (204). Transpiration continued even in a saturated atmosphere. The accelerating effect of radiation on transpiration seems to depend on temperature differences between the air and the leaf. But no evidence was obtained to indicate cooling by transpiration, since actively transpiring leaves were not significantly cooler than those reduced to the wilting point.

Reynolds (175) suggests that the evaporative cooling effect of transpiration may extend into the interior of the bole. He kept continuous records for 4 years of air, cambium, and center temperatures of a cottonwood tree. Under certain environmental conditions he observed a distinct thermostatic action controlling internal temperatures. He ascribed this to transpiration, since it was apparent only when the tree was in foliage. When the air temperature rose rapidly in summer the center temperature began dropping. He theorizes that tension in the water columns resulting from rapid transpiration causes water to evaporate, thus cooling the tree and keeping the cambium temperature below that of the air. 
Thermal emissivity of a leaf has been defined as the number of calories of heat given off per minute from a square centimeter of leaf surface for each degree of temperature difference between the leaf and the air (229). It is thus a measure of the radiation properties of a surface. According to Watson (228) emissivity rather than transpiration is the chief agent in preventing solar overheating of plant tissue; the proportion of available energy absorbed in transpiration does not indicate its true cooling value. Clum (51) found no consistent correlation between transpiration and leaf-air temperature difference, although leaves coated with vaseline were from $2^{\circ}$ to $4^{\circ} \mathrm{C}$. higher than transpiring leaves. Leaf temperature depended on insolation and not on water content, for a turgid leaf varied over as great a range as a dried one. He concluded that radiation and convection are more important than transpiration in controlling leaf temperatures. The two or three degrees that transpiration may cool the leaf are probably not important in protecting it from intense sunlight. Ansari and Loomis (8) essentially agree and conclude that leaf temperatures are controlled primarily by air temperature, radiation, air movement, and leaf mass, and only to a smaller and frequently insignificant extent by transpiration. In daylight leaf temperatures were always higher than air temperatures, and some leaves rose $20^{\circ}$ above air temperature in 60 seconds when exposed to direct sunlight. Wilted leaves showed temperature-time curves similar to those of turgid leaves, with only a $2^{\circ}$ difference accounted for by transpiration.

Thus thermal emissivity, and to a lesser extent, transpiration and other factors, may effect fire injury by their influence on initial temperature. Thermal emissivity may also play a direct part in fire damage. Radiation, particularly from a slow-moving backfire on the leeward side of the tree, raised the temperature of bark (and no doubt low foliage) considerably before the flame front arrived (64). This heat would be transmitted through the bark by conduction and raise the temperature of the cambium. The increase in initial temperature of living tissue from preliminary radiation may result in more injury as the flame passes the tree. The effect was especially evident from one to three feet above ground, where air temperatures on the trunk commonly reached sev- eral hundred degrees minutes before the flame front arrived.

Natural insulation.-Living cells in woody plants are insulated from excessive heat in various ways. Bark, with its numerous air cells and abundance of cork, is an excellent insulator (47), its efficiency varying with thickness, composition, structure, density, and moisture content (55). Cracks and fissures may be weak spots in the armor (76), but tests with longleaf pine indicate that the dead air space may act as an insulator (64). During fires air temperatures in fissures were as much as $500^{\circ}$ lower than the air above adjacent bark plates.

Bark thickness has often been linked with fire resistance (190), but other factors, mainly percentage of cork or outer bark, may override the effect of thickness (195). More than 1,000 tests on living trees of 14 species indicated that, for the same thickness, the bark of southern conifers (pines, baldcypress) was twice as good an insulator as that of cherry, holly, or sweetgum (91). Other hardwoods were intermediate in cambial fire resistance for a given bark thickness, except that the magnolias were relatively resistant.

Thermal conductivity of wood increases with moisture content (202); this is in contrast to the situation in soils, where moisture decreases heat penetration (17). Thus, if bark behaves as wood does, high moisture content may reduce its protection to the cambium. Amount of water in bark and wood fluctuates seasonally, being highest in spring and lowest in fall for most species (83). The obvious inference is that bark affords the best protection to trees in fall and winter, the least in spring. If the xylem acts as an effective heat sink, fluctuation in wood moisture content also increases fire resistance in fall and winter.

Bark characteristics are much more important in fire resistance than is indicated by their brief mention here. A forthcoming publication by Spalt and Reifsnyder (189) reviews knowledge on this subject comprehensively.

Examples of insulating tissues other than bark include seed coats, fruits, and bud scales. In some instances the position of the sensitive growing tip offers protection. Chapman (48) wrapped tissue paper around the buds of longleaf seedlings 1 to 3 feet high and found it unscorched after a hot fire. Apparently, insula- 
tion was provided by dense surrounding foliage, which was seared to within 3 inches of the paper. Little and Somes (131) point out that sprouting of pitch and shortleaf pine after a fire depends on dormant buds being protected by the basal crook of the seedlings, as well as by relatively thick bark.

\section{Intermediate Factors in Heat Resistance}

Species.-Specific differences in heat tolerance apparently stem more from external factors such as insulation than from any differences on the cellular level. Baker (13) states: "There is no evidence that the protoplasm of one species of vascular plant has a higher thermal tolerance than that of another when the protoplasm is well-hydrated and in an actively functional state." The importance of "well-hydrated" protoplasm must be stressed, for dehydration increases both heat and cold resistance (117). Since polar or xerophytic plants have few, if any, morphological features enabling them to withstand extremes of temperature, it is obvious that their heat and cold resistance must depend almost entirely on the composition or condition of the protoplasm (144). The protoplasm of many xerophytes contains large amounts of mucilages or pentosans that are unharmed by boiling and have great water-holding capacity.

Baker (12), Lorenz (134), and Shirley (183) found no significant differences between species of tree seedlings in relation to lethal temperatures. But Weddell and Ware (235) obtained large species differences in the survival of southern pine seedlings burned two years after planting: loblolly 18 percent survival, slash 32 percent, shortleaf (including sprouts) 56 percent, and longleaf 58 percent.

Variables between species that may affect relative fire resistance include bark thickness and composition, growth form, sprouting ability, typical growing site, and fuel accumulation in a typical site (190). Various attempts have been made to classify United States trees on the basis of their fire tolerance $(55,73,190)$. In the eastern United States longleaf pine is rated highest, followed by various other southern pines. These species occur in fairly open stands and have a relatively thick bark, a high open crown, and deep roots. Least resistant are certain hardwoods, firs, cedars, and spruces which grow in dense stands, and have thin bark, low dense crowns, and shallow roots. Allen (4) found hardwoods, especially the oaks and holly, less resistant than loblolly pine. Blackgum seemed more resistant than the other hardwoods. Jameson (113) found pinyon and juniper tissue much more resistant to heat and desiccation than the tissue of various grasses. Nakamura (157) rated 74 Japanese tree species according to the relative inflammability of their leaves and twigs.

Age and size.-The fire resistance of any tree increases with lignification, diameter, bark thickness, and elevation of the crown, all commonly associated with age $(12,33,170,178$, 222). Longleaf pine is a partial exception to this general rule because seedlings in the grass stage are much more resistant than those between 1 and $4 \frac{1}{2}$ feet in height (222). This is an effect of height more than of age, because other factors as well as age influence longleaf height growth. Bruce (33), however, found a correlation between age and fire mortality in longleaf pine seedlings.

Diseases, insects.-Although trees infested with insects and disease may be less resistant to fire injury than healthy trees on the basis of reduced vigor alone, other effects of pests are probably more important. Slash pines infected with fusiform rust are killed more readily by fire than are healthy trees, mostly because pitch from the cankers catches fire (185). Bruce (35) showed that brown-spot infected longleaf seedlings were much more susceptible to fire-kill than healthy seedlings, especially where the plant is more than two-thirds defoliated by the disease. He attributed this susceptibility more to the change of foliage from green insulation to dead fuel than to reduced plant vigor. Insects and rot following fire may also predispose the tree to more damage by enlarging the wound and exposing more area to later fires, which may eventually girdle or topple the trae.

\section{Physiological Factors in Heat Resistance}

Succulence, hardening.-Degree of succulence in mesophytic plants seems inversely associated with both dormancy and resistance to heat (or cold). Fast-growing, succulent tissues are very susceptible, whereas such hard and desiccated tissues as seeds, dormant twigs, 
and in lower forms spores, are heat and cold resistant. "In the dry state the protoplasm of seeds and spores has been found to withstand quite long exposures to temperatures less than $1^{\circ} \mathrm{K}$. $\left(-458^{\circ} \mathrm{F}\right.$. $)$ or more than $120^{\circ} \mathrm{C}$. $\left(248^{\circ} \mathrm{F}\right.$. $)$, while vigorously growing tissues tend to have little or no hardiness." (63). The effect of moisture content on heat resistance of seeds is well illustrated by Carmichael (44).

Even among actively growing plants, resistance is influenced by water content. Watered bluestem grass was killed in 4 hours by the same degree of heat that required 16 hours to kill drought-hardened bluestem (117). Hardening against heat is analogous to frost hardening, and the two effects seem to be reciprocal, i.e., hardening for frost resistance may increase heat resistance, and vice versa, indicating a common mechanism (126).

Konis (119) states that individual maquis plants are inured to heat by growing in a habitat which is consistently warm during the day. Such adjustment may simply be the product of increased osmotic values due to an increase in sugars and a decrease in water in the cells. Bukharin (39) proposes a unique mechanism to explain the increased heat resistance of plants held at $86^{\circ}$ for a short time. At this temperature protective hydrophilic colloids are at a maximum, and the coagulation temperature of protoplasm reaches a peak. Heat resistance decreases in plants held above $86^{\circ}$ because of a decline in the amount of hydrophilic colloids, as well as in the coagulation threshold of protoplasm. Thus at high temperatures the protective action of the hydrophilic colloids is lost and protoplasm coagulates at a lower temperature, with resultant loss of heat resistance.

The essential change in hardening of plants seems to be an increase in the ability of the proteins to absorb water (hydrophily) (63). Since this effect is common to all types of hardiness, one of the best ways to increase heat tolerance is to harden plants at very low temperatures. Low temperatures reduce the growth rate and salts and sugars accumulate in the cells. The result is an increase in osmotic pressure of the cell vacuoles and the withdrawal of water from the protoplasm. This in turn increases hydrophily in the plant.

The coagulation threshold of protoplasm may also be affected by the presence of auxins. In- doleacetic acid or 2, 4-D applied to sections of pea stems greatly reduced the amount of protein coagulated by heat from extracts of these tissues $(78,79)$. Total protein content was not altered, only the coagulation threshold. As auxin analogs that do not promote growth had little or no effect on coagulation, a physiological relationship was suggested, although the effect also occurred in roots where auxin inhibits growth. Auxins influenced stem protein coagulability most where auxin-induced growth was greatest and were ineffective where auxin did not influence growth. Gibberellic acid, which also promotes stem growth, enhanced the auxin effect on proteins. These data indicate that growth substances probably play a part in heat hardening.

Heat resistance of peas of both a heat-sensitive and a heat-resistant variety was markedly increased by vernalizing the seed for 25 days at $39^{\circ}(109)$. Growing the plants at high temperature devernalized them with respect to flowering but not with respect to heat resistance.

Phenology, dormancy, food reserves.Season of burning may influence not only direct fire damage, but also the ability of the plant to recover from injury by sprouting or refoliation. Foresters have observed that the best time to eradicate deciduous woody plants by cutting or burning usually is in spring, before the food reserves depleted by spring growth have been restored by the expanded leaves (237). Both shoot and root reserves in most deciduous trees peak in late summer, decrease slowly after leaf fall, and are depleted rapidly when active growth is resumed (172). Root reserves in Florida oaks reached a minimum in late April and early May, and a maximum in July (238). In evergreens the cycle may be reversed, as food accumulates in winter. Hepting (96) found a minimum of shoot and root reserves in shortleaf pine during fall, and a maximum in spring. On this basis a spring fire should cause greatest injury to deciduous trees with least loss to evergreens.

A burn during late April increased the number of buckbrush sprouts, a May burn decreased them (3). Starch reserves had been nearly depleted in the 23 days between the two burns. Sumac produced fewest sprouts when cut in June, when starch in this species was at a 
minimum. In the South, Chaiken (46) found summer fires more effective than winter fires in killing rootstocks and reducing size and vigor of sprouts from surviving rootstocks. Oak stumps in California sprouted less when cut in summer than in winter or early spring (133). In the southern Appalachians, dogwoods cut in early summer sent up fewer and less vigorous sprouts than those cut at any other time. Stumps from late-summer cuts had the most and longest sprouts (38). Similar results were obtained with oaks $(50,84)$ : quickest kill, least sprouting, and poorest survival of sprouts occurred when trees were girdled in May or June.

Food reserves seem to have a direct effect on heat resistance as well as on sprouting capacity. Julander (117) showed that hardening by drought under conditions favorable for food accumulation increased heat resistance of 5 grass species; in fact, any treatment that increased food reserves improved the resistance of the plant to heat.

Dormancy, particularly in deciduous trees, denotes lack of foliage to be injured by fire as well as the presence of dormant buds, which are presumably more heat-resistant than actively growing terminal buds. It is also conceivable that dormant cambium may be more tolerant of high temperatures than active cambium. If so, then any of the external or internal factors which, according to Wareing (227), control and modify cambial activity, may also influence fire resistance. Evidence indicates that growing buds produce auxin which initiates cambial activity. The presence of this auxin in itself may modify the heat resistance of the protoplasm (78).

Chemical factors.-Chemical reactions unrelated to auxins and food reserves also influence heat resistance. Heat effects sometimes can be alleviated chemically by supplying a deficiency or removing a toxin produced at high temperatures. Mitchell and Houlahan (153) studied a temperature-sensitive mutant of the red bread mold (Neurospora) which grows normally up to $77^{\circ}$ but ceases to grow above $82^{\circ}$; the normal parent grows well at $95^{\circ}$ to $104^{\circ}$. The mutant was unable to produce the essential nutrient riboflavin at elevated temperatures, but addition of this vitamin restored high-temperature growth. Other temperature-sensitive Neurospora mutants were cured by the addition of adenine and pyrimidines.
Results similar to those with molds have been obtained with higher plants. Peas, for example, turn yellow and die in a few days at $95^{\circ}$ even when water and mineral supplies are adequate. Galston and Hand (77) showed that this response has a chemical basis in that adenine, an essential growth factor, becomes deficient at high temperatures. Supplying adenine through the roots largely prevented yellowing and death. Peas of a heat-sensitive variety contained equal amounts of adenine at both high and low temperatures, but in a heat-resistant strain the adenine content doubled when temperatures were increased from $57^{\circ}$ to $78^{\circ}$ (108), indicating increased requirements at higher temperatures. Addition of adenine for protection against high temperature has also been reported for duckweed (120), bean, grape, and peach leaves (118). Heat lesions in mouse-ear cress were alleviated by supplying thiamine, adenine, pantothenic acid, biotin, and similar compounds (123). In fact, one characteristic of mutants that are sensitive to high temperature is the frequency with which they are reparable by single diffusable substances (10). Chemical control of climatic diseases may have practical value in extending the range of economic plants (120).

Although enzymes are easily inactivated by heat (152, pp. 466-467), their role in heat injury is unknown. By one theory, heat injury is initially due to the denaturation of specific thermolabile enzymes. The chief difficulty here is the relatively low temperature at which heat injury occurs in some plants, but it may be that enzymes are more thermolabile in vivo than in vitro (63). Support for this theory comes from numerous cases, as those cited above, in which heat injury is reparable by single compounds that presumably replace the heat-inactivated part of the enzyme. However, there is no evidence that inactivation of the enzyme peroxidase is accomplished at a lower temperature in vivo, since it remains active even after the cells have been killed by heat (personal observation).

Some strains of Neurospora apparently have more stable enzymes and hence are able to withstand more heat than others (63). Several enzymes are known to exist in forms that vary in thermostability. Possibly breeding for heat resistance could be accomplished by selecting genes that provide thermostable enzymes. 
Desert plants are remarkably tolerant of high temperature, as has already been shown. Roots of the creosote bush grow ten times as fast at 86 to $95^{\circ}$ as they do at 68 to $77^{\circ}$, the optimum temperature range for mesophytic plants. Mesquite roots grow rapidly at $106^{\circ}(120)$. The mechanism permitting xerophytic plants to withstand such temperatures is not known. Petinov and Molotkovsky (171) propose that the reparative capacity of heat-resistant cells is based on the production of the necessary organic acids, from which amides are synthesized. These amides eliminate the toxic effect of ammonia produced at high temperatures. Other theories of heat resistance are reviewed by Levitt (126).

Sprouting ability.-Because many hardwoods sprout from the base after the top has been killed (133), a single prescribed fire frequently results in many more stems than there were originally $(69,170)$. Most pines lack this sprouting ability, or lose it beyond the seedling stage. Thus, loblolly seedlings will not sprout after 7 or 8 years (132). In a severe fire which kills all tops, hardwoods therefore have the advantage over the typically more fire-resistant pines.

Notable exceptions to this general rule include pitch pine and shortleaf pine, which sprout from axillary buds or dormant buds under the bark. Shortleaf tops are less fireresistant than other southern pines but the species' sprouting ability gives it an advantage in severe fires. Basal sprouts have been reported from pitch pines up to 79 years old and shortleaf up to 70 years (131). Pitch pine in New Jersey's Plains areas, subject to frequent fires, forms characteristic large clumps which may have as many as 249 living 1-year-old sprouts on a single stool.

Recovery processes.-The physiological processes accompanying recovery from fire damage apparently have received little attention. Defoliation may be followed by growth of new leaves if the tree or buds have not been killed. As long as a leaf is healthy it exerts apical dominance, so that the axillary leaf bud is prevented from growing. In the South, refoliation following fire is seen most frequently in pines, for in hardwoods the tops, twigs, or buds are likely to be killed if the fire is hot enough to kill the leaves.
Wound healing is accomplished by callus tissue which grows in from all sides, eventually closing the wound if it is not too large and is not attacked by insects or fungi. Fingers of callus (and presumably cambium) can often be seen within the wound. The origin of callus tissue seems debatable. Usually it is assumed to arise from the surrounding cambium (170), but Soe (186) found that the cambium took very little part in callus formation in hardwoods following scoring to the wood. Callus originated from ray cells or phloem parenchyma on both sides of the wound. About a week after joining, this tissue gave rise to a new vascular cambium. In the species studied, cork cambium was always formed ahead of vascular cambium.

\section{EXPERIMENTAL METHODS, INSTRUMENTATION}

\section{External Evidence of Heat Injury}

Color changes.-Color provides a convenient and rapid method for diagnosing heat injury in those species where browning or yellowing occurs soon after the plant has lost its ability to recover (168). Nelson (159) used yellowing of southern pine needles as an identification of heat injury following immersion in a water bath.

Subsequent growth.-Measurement of subsequent growth is the most reliable method of assaying physiological heat injury and often the most practical, but sufficient time must be allowed to assure that delayed effects will not be missed. Ursic (213) found that many pine seedlings appeared normal for two months before they died of heat treatment.

Bark and crown scorch.-Scorch is the most commonly accepted diagnostic criterion of injury after a fire. Many attempts have been made to assay damage on this basis, with varying success. Degree of crown scorch seems the best indicator $(68,69,151,220)$. Adding an estimate of cambium injury to estimates of defoliation may improve the accuracy of mortality predictions $(68,151)$. Nelson et al. (162), maintain that the area of a wound can be predicted in the first growing season after a fire from such measurements as the height and width of the discolored area of bark and d.b.h. (as correlated with bark thickness), but Stickel (194) believes it necessary to wait several years to predict damage accurately. 
Pitch flow.-Obvious pitch flow is a good indication of cambium injury in pines, although it may not occur in all species or at all seasons. Several weeks after prescribed burning of longleaf pine in April the cambium under areas of pitch flow was examined, either visually or electrically (64). Discoloration, or an increase in electrical resistance (90), showed that the cambium had been killed in all of these areas. Dogwood and some other hardwoods also exude gum from fire wounds under the bark (personal observation).

\section{Internal Evidence of Heat Injury}

Various changes, e.g., in the appearance of internal tissues, response of cells to dyes, tissue fluorescence, cytoplasmic streaming, electrical resistance, gas exchange, and enzyme activity may be used as indications of plant injury. The method of diagnosis used is determined by the species, tissue, and specific problem (168).

Appearance of cambium.-Cambial fire injury is usually hidden by the bark, which may remain attached for several years before being split off by the swelling callus (122). Diagnosis by direct cambium examination therefore requires removal of the bark (151), a time-consuming and injurious process.

Electrical resistance in the cambium.-Tests in south Mississippi have indicated a relationship between electrical resistance and heat injury in the cambium (90). Resistance was measured with a modified lumber moisture meter having long probes sensitive only at the tips. Readings in the cambial region dropped sharply within a week after heat-killing, indicating an increase in resistance, presumably due to loss of moisture. Resistance readings may thus provide a rapid and non-injurious method for assaying cambial damage. Moisture-meter indications corresponded well with direct examination (64).

Most workers report a decrease, rather than an increase, in electrical resistance following death $(58,72,87,140,165)$. Osterhout (165) was the first to demonstrate that resistance to low-frequency alternating current decreased with injury, then fell to a low level at death. This resistance drop preceded visible signs of death by several days. The tissue to be measured was immersed in water of high electrolyte content. Greenham et al. $(87,88)$ found that, when measurements were made in situ with a lower electrolyte content, loss of moisture following death increased the resistance. Thus a dead and partially desiccated root had the same low-frequency resistance as a healthy root. This may be the effect observed in tree cambium following death. The cambial region is high in moisture and low in electrolytes, so that desiccation following death would increase the electrical resistance.

In order to avoid the effect of desiccation Greenham $(58,88)$ used a ratio of low-frequency resistance to high-frequency resistance. This ratio is not affected by water content and is approximately 1 in dead tissue. The ratio is very high in healthy tissue, may increase with initial injury, but decreases with further injury from such causes as poisons, cold, heat, or drought.

The drop in low-frequency resistance at death where desiccation is not a factor is believed due to the action of the plasmalemma, or cell membrane. This membrane effect has been questioned (111), but Walker (226) demonstrated its existence with direct-current measurements. Luyet (140) observed that with high frequencies resistance in both living and dead tissues was low, whereas with low frequencies resistance was much higher in living tissues. The drop in low-frequency resistance provided an instantaneous measure of death. The plasmalemma seems to act like a capacitance in living cells, imposing a high impedance on low-frequency current (58). At death this capacitance effect breaks down. Resistance in healthy tisue would then be the sum of electrolyte resistance plus the capacitive impedance of the plasmalemma. With high frequencies death has no effect, because capacitive impedance is very low; with low frequencies the impedance is great until destroyed by death.

Filinger and Cardwell (72) used electricalresistance measurements to detect killing of raspberry canes by freezing or boiling. Electrodes were inserted 10 inches apart, and were connected to a resistance bridge and source of 1000-cycle alternating current. Resistance increased from 72 to 90 percent following death of the stems.

There is very little literature regarding electrical resistance measurements in tree cambium. Fensom (67) used silver nails set in the 
cambium to measure resistance in maple branches. The resistance decreased with declining temperature and with the onset of phenological stages such as sap flow, budding, flowering, and leaf opening.

Russian work (241) indicates that the moisture content, thickness, $\mathrm{pH}$, and electrical properties of pine phloem may be changed by fungus infections. In addition, the catalase activity of the inner bark and needles and the starch content of phloem parenchyma show differences between healthy trees and those attacked by Fomes annosus and other fungi. If heat also affects some of these properties, measurement of them could be used in assaying fire injury.

Another Russian paper (158) describes four instruments for determining cambial moisture differences between normal and diseased trees. The instruments make use of cobalt chloride paper, expressed sap volume, or galvanomic output from bimetallic electrodes pressed against the cambium. All four are said to be highly reliable. Tests on oak, pine, chestnut, ash, and other species showed a consistently lower cambial moisture content in diseased trees.

Cytological examination. - Lorenz (134) tried various means of assessing cell injury in cortical parenchyma. These included (1) direct observation of the plant material, which may require 2 days to 2 weeks before lethal effects become apparent; (2) use of ultraviolet absorption, in which living cells appear black in an ultraviolet photograph and dead cells appear white; and (3) staining with neutral red and methyl blue, so that living cells show up red and dead cells blue.

Lorenz decided on a simple, neutral red stain; at death the cell membrane loses its permeability and does not absorb this dye. Monselise (154) used sodium selenite and indigo carmine to determine viability in citrus seed. Living cells were stained red by reduction of selenite to red selenium by enzyme action, while dead cells were stained blue by indigo. Much work has been done recently with tetrazolium chloride (TTC) as a vital stain $(30,85,113,166,167,-177)$. This compound is reduced to an insoluble red formazan by enzymes in living cells, making visible numerous cell structures that contain the en- zymes. The value of tetrazolium chloride for pine studies is questionable, because resin also reduces it (167).

Observation of cytoplasmic streaming constitutes an easy visual method of studying heat effects in tissues where streaming occurs, although streaming may stop before the cell is killed. Thimann and Kaufman (205) found that rate of streaming in cambial cells of white pine was proportional to temperature up to $93^{\circ}$. At higher temperatures the rate decreased. All streaming stopped at $110^{\circ}$. This happens to be the temperature at which Bukharin (39) found that protoplasm reached its maximum viscosity. If irreversible coagulation occurs at $110^{\circ}$, this would be the lethal temperature of the protoplasm, although it seems low. Thimann and Kaufman's data do not indicate that brief exposure to this temperature is lethal. Some damage occurred, however, for when cells were returned to lower temperatures streaming was resumed at a reduced rate.

Luyet and Gehenio (141) used ultraviolet absorption to differentiate between living and dead cells in onion epidermis. A microscope with quartz lenses was used to transmit the ultraviolet. Living cells absorbed ultraviolet and photographed black, whereas dead cells showed up white. Cells lost the power of absorption when heated, poisoned, frozen, or injured. Apparently some living cells contain a natural pigment that absorbs ultraviolet and is lost at death (142). The effect could be simulated in cells lacking the pigment by the use of neutral red stain and green light, in which case living cells again appeared black and became transparent at death.

Enzyme detection and respiration measurements.-Colorimetric enzyme tests, similar to those used for peroxidase in blanching vegetables (155), may possibly be useful for assaying fire damage. However, most enzymes have inactivation temperatures higher than the general lethal temperature of plant tissue. Measurement of gas exchange is another physiological test which would determine viability, by indicating whether respiration was taking place.

\section{Methods of Heat Application}

Of many different methods of applying controlled heat to plants, immersion in a water 
bath $(12,82,134,183,213)$ has been the most popular. Uniform temperatures are easily maintained, and conduction of heat into plant tissue is rapid. Other heat sources used include ovens $(12,16)$, radiant electric heaters $(12,16$, 59 ), a hot plate (195), solar heating in a blackened bottle (119), sprinkling hot sand over seedlings planted in soil (178), electric heating in a synthetic bale (213), slash burning (240), and a propane torch (91), kerosene wick or hot air blower $(187,188)$. Lorenz (134) used a heated microscope stage, thermostatically controlled, by which he could observe cellular heat effects directly.

MacLean (147) points out that the rate of heat movement through a body is affected by the method of heating as well as by the temperature difference between the heat source and the body. For a given temperature at the source he found steam to be the most effective, followed by water, creosote, and hot plates. Differences in heat source efficiency may be ascribed to surface resistance or intimacy of contact. Changes in bark properties with charring is another variable that must be considered.

\section{Techniques For Measuring Temperature}

The problems connected with measurement of temperature, both external and internal, involve mainly considerations of accuracy, fast response, sufficient range, and ability to place the sensitive element within the desired tissue with a minimum disturbance to the physical structure. The thermocouple appears to meet these requirements best. Eggert (61) discusses the construction and installation of thermocouples for biological research. He describes a method for inserting thermocouples in tree trunks, and emphasizes the use of fine wire to insure rapid response to quick changes in temperature. Further applications in agricultural research are discussed by Lorenzen (135).

Considerable information is available on thermocouple fundamentals, applications, and sources of error $(65,169,174,176,203,219)$. The construction of micro-thermocouples, necessary for rapid response and minimum disturbance of tissue, has been approached in several ingenious ways $(135,215,236)$. The National Bureau of Standards has published two lists of references on temperature measurement $(75,211)$.
Some specific applications of the thermocouple in studies of heat effects in trees might be mentioned. Devet (59) used 24-gage wire for bark-surface temperatures and 36-gage for the cambium, the latter being inserted in a hole made by a needle. Vehrencamp (214) measured air temperatures during fires with 24-gage iron-constantan couples. Radiation shields were unsatisfactory. Leads were insulated with asbestos and glass. Protection of leads exposed to flame is a major problem; Davis and Martin (56) used fiberglass-stainless steel mesh insulation. Some sort of metallic armor seems to be the only flexible insulation capable of withstanding repeated exposure to flame. In south Mississippi (64) extension wire leads insulated with asbestos were carried through flexible steel conduit to a buried junction box containing a common reference junction. At the tree the exposed leads were protected by ceramic insulators. External thermocouples were 22-gage iron constantan and internal couples were 28-gage IC enclosed in stainless steel for insertion under the bark. Temperatures were recorded automatically at 2 -second intervals on a 16-point Brown recorder, or manually on a portable potentiometer (64).

Shcherbakov (182) described an electric thermometer, possibly a thermistor, for measuring tree temperatures. Uggla (209) used resistance bridges to obtain air and soil temperatures during fires. Thermistors are adapted to precise measurement of a narrow range of temperatures $(19,116,208)$; thermocouples have a wider range, and are much cheaper.

Non-electric methods of temperature measurement often make use of the melting points of various substances. The fusible compounds indicate only minimum temperatures, i.e., whether the melting point of each compound has been reached. Nelson and Sims (161) employed Seger cones and metal alloy ribbons for determining maximum temperatures at various levels in a forest fire, while Beadle (17) made use of the melting points of various organic compounds placed in buried vials to measure soil temperatures during a fire. Fenner and Bentley (66) painted solutions of different compounds in strips on sheets of mica. When the solvent had evaporated the crystals were left and could be observed for fusion. The 
sheets of mica were buried in the soil vertically so that depth of each fusion temperature could be observed. These methods obviously are unsuited to measurement of internal temperatures of living organisms.

\section{SUMMARY OF RESEARCH NEEDS}

Although many things related to the problem of fire tolerance in trees have been mentioned in this review, it is clear that very little is known about the subject. The ensuing discussion considers, in the approximate sequence that it should be developed, the information that seems most important to an understanding of the subject. Each section indicates the status of knowledge as uncovered in the literature review, and thus serves as a summary.

\section{Temperature Measurement During Fires}

Basic to further study of fire injuries to trees are records of temperatures and their durations both immediately external to plants and in the tissues themselves. The records should be obtained from fires that burn in natural fuels and are hot enough to kill or wound. Then, with readily controlled heat sources, simulated forest fires could be designed for further studies. This approach would eliminate waiting for the right weather conditions; remove worry about causing excessive timber loss; and facilitate replications of conditions of exposure.

\section{Thermal Characteristics of Bark}

Most fire damage to trees is stem injury or defoliation, although buds can be killed and roots injured. Thus the protection afforded the stem by bark is an important factor in resistance. It is apparent and often reported that thick barks are better insulators than thin barks, and fire resistance ratings of the various species are largely assigned on the basis of bark thickness.

Such generalizations do not tell how much fire a given tree can stand, or help predict damage to individual trees. Laboratory studies, now under way or contemplated, can determine the physical constants involved-thermal conductivity and diffusivity, specific heat, density, and moisture content of inner and outer bark-and thus explain species differences and provide means for predicting damage from fires of known intensities. There also is room for empirical field tests to uncover interspecific differences other than bark thickness, and help in the interpretation of laboratory findings.

\section{Identification of Internal Heat Injury}

Before high-temperature effects on cells or tissues can be studied, before lethal temperatures can be determined, a technique is needed for differentiating between living and dead material. At present the most reliable method for assaying damage to tissue is by observing subsequent growth, but this sometimes takes too much time.

Foliage injury and cambium browning indicate localized death of plant parts but not necessarily death of the tree. The cambium may discolor slowly and examination of it further injures the tree. A rapid, reliable, and relatively non-injurious assay method is needed. Even methods dealing with individual cells or small groups of cells have not been entirely satisfactory. Microscopic observation of vital staining, cytoplasmic streaming, or plasmolysis is tedious and interpretation in terms of damage to living trees is uncertain.

The rapid identification of injured tissue in the field is therefore an important goal. At present, electrical-resistance measurements seem promising, but more work is needed on factors other than death that affect resistance in the cambium. Stains and other reactions of living tissue that can be observed in the field should be investigated. There may be a chemical response to wounding that could be made the basis of a diagnostic test (148).

\section{Lethal Time-Temperature Curves}

Some data are now available on how long foliage, seeds, and seedlings can endure various high temperatures. This kind of information is needed for different parts of trees. Controlled heat sources and accurate measurement of internal temperatures are necessary. The effect of such factors as moisture content, age, and species should be studied.

\section{Physiological Effects of High Temperature}

There is little information on the effect of near-lethal temperatures on physiological functions, yet such data might reveal how cells or tissues are injured by heat. Among the many 
possibilities are changes in respiration, in translocation of food, water or growth substances, or in enzyme reactions.

Secondary physiological effects caused by partial or complete girdling of stems have received some attention. Changes in moisture content of leaves are apparently slight, but rariations in sprouting have been described for fires of different intensities and in different seasons. Some of these effects may be explained by destruction of basal (dormant) buds and the effect of current food reserves.

The effect of temperature on respiration in plants is well known (152) but forest fires usually pass too swiftly to have much permanent direct effect on plant respiration. Translocation of foods and other metabolites might very well be influenced if phloem were injured. Sub-injurious temperatures affect phloem transport (62) but the same objections of short duration hold here. Enzymes are easily inactivated by heat but usually only at temperatures above those which would be lethal for the cell itself. Thus, translocation may be the chief physiological function disrupted by damaging high temperatures, and this only until uninjured conductive tissue becomes adapted to bypass the wound. Research to determine if translocation is an important factor in heat injury would require radioactive or other types of tracers. Active enzymes could be identified chemically after heat treatment.

\section{Importance of Various Factors in Fire Resistance}

Besides the obvious external factors that affect fire injury, such as temperature and duration, there are several internal conditions which alter high temperature effects. Species differ in bark and growth habit, e.g., succulent plants are more susceptible than hardened ones. Age, vigor, degree of dormancy, and food reserves also affect heat tolerance.

The initial approach to the study of these factors as they affect high temperature tolerance will require greenhouse studies on seedlings, perhaps with field observations on mature trees to follow. Season, as it affects moisture content of bark, as well as succulence in living tissue, may be important. The relationship between chemistry of the plant (adenine content, e.g.) and heat resistance needs to be studied, as does the possibility of hardening for heat resistance. Moisture content must be known or controlled, not only to standardize results but to determine its effect on heat resistance.

\section{Recovery Processes}

The processes of recovery in fire-damaged tree tissues have received little attention. When a spot of cambium is killed callus tissue forms, whether from cambium, ray cells, or phloem parenchyma, and eventually covers the lesion if it is not too large. But what physiological processes accompany this growth? Knowledge of the part played by growth substances, enzymes, food, minerals, and other metabolites might lead to means of accelerating the healing process itself. 
(1) Ahlgren, Clifford E.

1959. SOME EFFECTS OF FIRE ON FOREST REPRODUCTION IN NORTHEASTERN MINNESOTA. Jour. Forestry 57:194-200, illus.

(2)

1960. SOME EFFECTS OF FIRE ON REPRODUCTION AND GROWTH OF VEGETATION IN NORTHEASTERN MiNNESOTA. Ecol. 41:431-445, illus.

(3) Aldous, A. E.

1929. THE ERADICATION OF BRUSH AND WEEDS FROM PASTURE LANDS. Jour. Amer. Soc. Agron. 21:660-666.

(4) Allen, Peter H.

1960. SCORCH AND MORTALITY AFTER A SUMMER BURN IN LOBLOLLY PINE. U. S. Forest Serv. Fire Control Notes 21: 124-125.

(5) Alway, F. J., and Rost, C. C.

1928. EFFECT OF FOREST FIRES UPON THE COMPOSITION AND PRODUCTIVITY OF THE SOIL. Internatl. Cong. Soil Sci. Proc. 3:546-576.

(6) Anderson, D. A., and Balthis, R. F.

1944. EFFECT OF ANNUAL FALL FIRES ON THE TAPER OF LONGLEAF PINE. Jour. Forestry $42: 518$

(7) AndRESEN, JoHN W.

1959. A STUDY OF PSEUDO-NANISM IN Pinus rigida MILL. Ecol. Monog. 29:309-332, illus.

(8) Ansari, A. Q., and Loomis, W. E.

1959. LeAF temperatures. Amer. Jour. Bot. $46: 713-717$, illus.

(9) Applequist, M. B.

1960. EFFECTS OF CLEARED-AND-BURNED HARDWOOD SLASH ON GROWTH OF PLANTED LOBLOLLY PINE IN LIVINGSTON PARISH, LOUISIANA. Jour. Forestry 58:899-900.

(10) Atwood, K. C., and MukaI, F.

1953. INDISPENSABLE GENE FUNCTIONS IN NEUROsPora. Natl. Acad. Sci. Proc. 39:10271035.

(11) Austin, R. C., and Baisinger, D. H.

1955. SOME EFFECTS OF BURNING ON FOREST SOILS OF WESTERN OREGON AND WASHINGTON. Jour. Forestry $53: 275-280$, illus.

(12) BAKER, F.S.

1929. EFFECT OF EXCESSIVELY HIGH TEMPERATURES ON CONIFEROUS REPRODUCTION. JOUT. FOrestry $27: 949-975$, illus.

(13)

1950. PRINCIPLES OF SILVICULTURE. 414 pp., illus. New York.

(14) Balthis, R. F., and Anderson, D. A.

1944. EFFECT OF CULTIVATION IN A YOUNG SLASH PINE PLANTATION ON THE DEVELOPMENT OF CRONARTIUM CANKERS AND FORKED TREES. Jour. Forestry 42:926-927.
(15) Barnette, R. M., and Hester, J. B.

1930. EFFECT OF BURNING UPON THE ACCUMULATION OF ORGANIC MATTER IN FOREST SOILS. Soil Sci. 29:281-284, illus.

(16) Bates, C. G., and Roeser, J., Jr.

1924. RELATIVE RESISTANCE OF TREE SEEDLINGS to Excessive heat. U. S. Dept. Agr. Bul. 1263, 16 pp., illus.

(17) Beadle, N. C. W.

1940. SOIL TEMPERATURES DURING FOREST FIRES AND THEIR EFFECT ON THE SURVIVAL OF VEgetation. Jour. Ecol. 28:180-192, illus.

(18) Beaufait, William R.

1960. SOME EFFECTS OF HIGH TEMPERATURES ON THE CONES AND SEEDS OF JACK PINE. Forest Sci. 6:194-199, illus.

(19) Becker, J., Green, C., and Pearson, G.

1946. PROPERTIES AND USES OF THERMISTORSTHERMALLy SENSITIVE RESISTORS. Amer. Inst. Elec. Engin. Trans. 65:711-725, illus.

(20) BELEHRADEK, J.

1935. Temperature and living matter. Protoplasma Monog. 8, 277 pp., illus.

(21) Bentley, J. R., and Fenner, R. L.

1958. SOIL TEMPERATURES DURING BURNING RELATED TO POSTFIRE SEEDBEDS ON WOODLAND RANGE. Jour. Forestry 56:737-740, illus.

(22) Bergstrom, $\mathrm{H}$.

1958. TEMPERATURES IN THE TRUNK OF LIVING TreEs. Svensk PappTidn. 61 (20):902, illus.

(23) BICKFORD, C. A.

1942. THE USE OF FIRE IN THE FLATWOODS OF THE SOUtheAst. Jour. Forestry 40:132-133.

(24) and Bull, Henry.

1935. A DESTRUCTIVE FOREST FIRE AND SOME OF its implications. U. S. Forest Serv. South. Forest Expt. Sta. Occas. Paper 46, $4 \mathrm{pp}$.

(25) and Curry, J. R.

1943. THE USE OF FIRE IN THE PROTECTION OF LONGLEAF AND SLASH PINE FORESTS. U. S. Forest Serv. South. Forest Expt. Sta. Occas. Paper 105, 22 pp., illus.

(26) Bigelow, W. D.

1921. THE LOGARITHMIC NATURE OF THERMAL DEATH CURVES. Jour. Infectious Diseases $29: 528-536$, illus.

(27) Boggess, W. R., and Stahelin, R.

1948. THE INCIDENCE OF FUSIFORM RUST IN SLASH PINE PLANTATIONS RECEIVING CULTURAL treatments. Jour. Forestry 46:683-685.

(28) Boyd, Helen.

1952. BURNING FOR CONTROL OF BRUSH AND BROWN SPOT DISEASE: SELECTED REFERENCES. U. S. Dept. Agr. Library, (Louisiana Branch, New Orleans). 
(29) Brown, James H., Jr.

1960. THE ROLE OF FIRE IN ALTERING THE SPECIES COMPOSITION OF FORESTS IN RHODE ISLAND. Ecol. $41: 310-316$, illus.

(30) Brown, Walter.

1954. A PRELIMINARY STUDY OF THE STAINING OF PLANT CELLS BY TETRAZOLIUM CHLORIDE. Bul. Torrey Bot. Club 81:127-136, illus.

(31) Bruce, David.

1949. SOIL ANALYSIS OF H-2 plots. U.S. Forest Serv. South. Forest Expt. Sta. Office Rpt. [Unpublished.]

(32)

1951. FIRE, SITE, AND LONGLEAF HEIGHT GROWTH. Jour. Forestry 49: 25-28, illus.

(33)

1951. FIRE RESISTANCE OF LONGLEAF PINE SEEDLINGS. Jour. Forestry $49: 739-740$.

(34)

1951. A STUDY OF AVERAGE PINE MORTALITY CAUSED By FIRE. U. S. Forest Serv. South. Forest Expt. Sta. Office Rpt., 21 pp., illus. [Unpublished.]

(35)

1954. MORTALITY OF LONGLEAF PINE SEEDLINGS After A WiNter fire. Jour. Forestry 52: 442-443, illus.

(36)

1957. FOREST FIRE RESEARCH NEEDS IN THE SOUTH. U. S. Forest Serv. South. Forest Expt. Sta. Problem Analysis, 28 pp., illus.

(37) and Nelson, RALPH M.

1957. USE AND EFFECTS OF FIRE IN SOUTHERN FORESTS: ABSTRACTS OF PUBLICATIONS BY THE SOUTHERN AND SOUTHEASTERN FOREST EXPERIMENT STATIONS, 1921-55. U.S. Forest Serv. Fire Control Notes 18:67-96.

(38) BuelL, J. H.

1940. EFFECT OF SEASON OF CUTTING ON SPROUTING OF DOGWOOD. Jour. Forestry 38:649650 .

(39) Bukharin, P. D.

1958. LEAF TEMPERATURE AND HEAT RESISTANCE in CERTain Cultivated plants. Fiziol. Rast. (English transl.) 5(2):117-124, illus.

(40) Burns, P. Y.

1952. EFFECT OF FIRE ON FOREST SOILS IN THE PINE BARREN REGION OF NEW JERSEY. Yale Univ. School Forestry Bul. 57, 50 pp., illus.

(41) Byram, George M.

1948. VEGETATION TEMPERATURE AND FIRE DAMAGE IN THE SOUTHERN PINES. U. S. Forest Serv. Fire Control Notes 9 (4) :34-36, illus.
(42)

1957. SOME PRINCIPLES OF COMBUSTION AND THEIR SIGNIFICANCE IN FOREST FIRE BEHAVIOR. U. S. Forest Serv. Fire Control Notes 18: 47-57, illus.

(43)

1958. SOME BASIC THERMAL PROCESSES CONTROLLING THE EFFECTS OF FIRE ON LIVING VEGETATION. U. S. Forest Serv. Southeast. Forest Expt. Sta. Res. Note 114, 2 pp., illus.

(44) Carmichael, Alan J.

1958. DETERMINATION OF MAXIMUM AIR TEMPERATURE TOLERATED BY . . SEEDS AT LOW RELATIVE humidities. Forestry Chron. 34 ; $387-392$, illus.

(45) CARY, Austin.

1932. SOME RELATIONS OF FIRE TO LONGLEAF PINE. Jour. Forestry 30:594-601, illus.

(46) Chaiken, L. E.

1952. ANNUAL SUMMER FIRES KILL HARDWOOD ROоT stocks. U.S. Forest Serv. Southeast. Forest Expt. Sta. Res. Note 19, 1 p

(47) Chang, Ying Pe.

1954. BARK STRUCTURE OF NORTH AMERICAN CONIFERS. U.S. Dept. Agr. Tech. Bul. 1095 86 pp., illus.

(48) Chapman, H. H

1936. EFFECT OF FIRE IN PREPARATION OF SEEDBED FOR LONGLEAF PINE SEEDLINGS. Jour, FOrestry $34: 852-854$

(49)

1942. EFFECT OF ANNUAL SPRING FIRES ON STUMP TAPER OF LOBLOLLY PINE. Jour. Forestry $40: 962-963$

(50) Clark, F. B., and Liming, F. G.

1953. SPROUTING OF BLACKJACK OAKS IN THE MISSOURI ozarks. U. S. Forest Serv. Cent. States Forest Expt. Sta. Tech. Paper 137, 22 pp., illus.

(51) Clum, H. H

1926. THE EFFECT OF TRANSPIRATION AND ENVIRONMENTAL FACTORS ON LEAF TEMPERATURES. I. TRANSPIRATION. II. LIGHT INTENSITY. Amer. Jour. Bot. 13:194-230, illus.

(52) Conarro, Raymond M.

1942. THE PLACE OF FIRE IN SOUTHERN FORESTRY. Jour. Forestry 40: 129-131.

(53) Cooper, Charles F.

1960. CHANGES IN VEGETATION, STRUCTURE, AND GROWTH OF SOUTHWESTERN PINE FORESTS Since White. Settlement. Ecol. Monog. $30: 129-164$, illus.

(54) Craighead, F. C.

1927. ABNORMALITIES IN ANNUAL RINGS RESUlTING FROM FIRES. Jour. Forestry 25:840842 , illus. 
(55) Davis, Kenneth P.

1959. FOREST FIRE: CONTROL AND USE. 584 pp., illus. N. Y.

(56) Davis, L. S., and Martin, R. E.

1960. TIME-TEMPERATURE RELATIONSHIPS OF TEST HEAD FIRES AND BACKFIRES. U.S. Forest Serv. Southeast. Forest Expt. Sta. Res. Note 148, 2 pp., illus.

(57) DEMMON, E. L.

1935. THE SILVicUltural ASPECtS OF THE FORESTFIRE PROBLEM IN THE LONGLEAF PINE REGION. Jour. Forestry $33: 323-331$.

(58) De Plater, C. V., and Greenham, C. G.

1959. A WIDE-RANGE BRIDGE FOR DETERMINING INJURy AND DEATH. Plant Physiol. 34:661667 , illus.

(59) Devet, David D.

1940. HEAT CONDUCTION OF BARK IN CERTAIN SELECTED SPECIES. Unpublished thesis on file N.Y. State Col. Forestry Library, Syracuse. Illus.

(60) EgGert, Russell.

1944. CAMBiUm temperatures of PEACH AND apple trees in winter. Amer. Soc. Hort. Sci. Proc. $45: 33-36$.

(61)

1946. THE CONSTRUCTION AND INSTALLATION OF THERMOCOUPLES FOR BIOLOGICAL RESEARCH. Jour. Agr. Res. 72:341-355, illus.

(62) Esau, Katherine, Currier, H. B., and Cheade, V.I.

1957. PHYSIOLOGY OF PHLOEM. Ann. Rev. Plant Physiol. 8:349-374.

(63) Evans, L. T.

1959. THE CHEMICAL BASIS OF CLIMATIC RESPONSE in plants. Roy. Austral. Chem. Inst. Proc. $26: 222-224$.

(64) Fahnestock, George R., and Hare, Robert C. 1961. TEMPERATURES OF TREE TRUNK SURFACES AND SURROUNDING AIR IN FOREST FIRES. U. S. Forest Serv. South. Forest Expt. Sta. Progress Rpt. [Unpublished.]

(65) Farrar, G. L., and Platt, A. M.

1949. SOME FUNDAMENTALS OF TEMPERATURE measurement With thermocouples. Petroleum Engin. 21:5-10, illus.

(66) Fenner, R. L., and Bentley, J. R.

1959. A FUSION PYROMETER TO MEASURE SOIL TEMPERATURES DURING WILDLAND FIRES. U. S. Forest Serv. Fire Control Notes 20 : 124-125.

(67) Fensom, D. S.

1960. A NOTE ON ELECTRICAL RESISTANCE MEASUREMENTS IN Acer saccharum. Canad. Jour. Bot. $38: 263-265$, illus.
(68) Ferguson, E. R.

1955. FIRE SCORCHED TREES-WILL THEY LIVE OR DIE? La. State Univ. School Forestry, 4th Ann. Forestry Symp. Proc., pp. 102-112, illus.

(69)

1957. STEM-KILL AND SPROUTING FOLLOWING PRESCRIBED FIRES IN A PINE-HARDWOOD STAND IN TEXAS. Jour. Forestry $55: 426-429$, illus.

( 70$)$

1958. PRESCRIBED BURNING AS AN AID IN REGENERAting difficult areas. Soc. Amer. Foresters Gulf States Sect. Proc. 1958 Ann. Meeting, pp. 35-41.

(71) Gibbs, C. B., and Thatcher, R. C. 1960. "COOL" BURNS AND PINE MORTALITY. U.S. Forest Serv. Fire Control Notes 21:27-29, illus.

(72) Filinger, G. A., and Cardwell, A. B.

1941. A RAPID METHOD OF DETERMINING WHEN A PLANT IS KILLED BY EXTREMES OF TEMPERATures. Amer. Soc. Hort. Sci. Proc. $39: 85-$ 86 , illus.

(73) FliNT, H. R.

1925. FIRE RESISTANCE OF NORTHERN ROCKY MOUNTAIN Conifers. Idaho Forester 7:7-10, 41-43.

(74) Fowells, H. A., and Stephenson, R. E.

1934. EFFECT OF BURNING ON FOREST SOILS. Soil Sci. $38: 175-181$.

(75) Freeze, Paul D.

1951. BIBLIOGRAPHY ON THE MEASUREMENT OF GAS temperature. U. S. Dept. Com., Natl. Bur. Standards Cir. 513, 14 pp.

(76) Fritz, Emanuel.

1932. THE ROLE OF FIRE IN THE REDW.OOD REGION. Calif. Agr. Expt. Sta. Cir. 323, 23 pp., illus.

(77) Galston, Arthur W., and Hand, M. E.

1949. ADENINE AS A GROWTH FACTOR FOR ETIOLATED PEAS AND ITS RELATION TO THE THERMaL inactivation of GRowth. Arch. Biochem. 22:434-443, illus.

(78) and KAUR, R.

1959. AN EFFECT OF AUXINS ON THE HEAT COAGULABILITY OF THE PROTEINS OF GROWING Plant Cells. Natl. Acad. Sci. Proc. 45: $1587-1590$.

( 79 ) Kaur, R., Maheshwari, N., and MAHESHW ARI, S. C.

1960. FURTHER EXPERIMENTS ON AUXIN-INDUCED ALTERATION OF THE HEAT COAGULABILITY OF PEA Stem Proteins. Plant Physiol. Suppl. 35 :xxvii. (Abstract.)

(80) Garren, K. H.

1941. FIRE WOUNDS ON LOBLOLLY PINE AND THEIR RELATION TO DECAY AND OTHER CULL. Jour. Forestry $39: 16-22$, illus. 
(81) Garren, K. H.

1943. EFFECTS OF FIRE ON VEGETATION OF THE Southeastern united states. Bot. Rev. $9: 617-654$, illus.

(82) Gentile, A. C., and Johansen, R. W.

1956. HEAT TOLERANCE OF SLASH AND SAND PINE SEedlings. U. S. Forest Serv. Southeast. Forest Expt. Sta. Res. Note 95, 1 p.

(83) GibBs, R. DARnley.

1958. PATTERNS IN THE SEASONAL WATER CONTENT of trees. The Physiology of Forest Trees, pp. 43-69, illus. N. Y.

(84) Grano, Charles $\mathrm{X}$.

1955. BEHAVIOR OF SOUTH ARKANSAS OAKS GIRDLED IN DIFFERENT SEASONS. Jour. Forestry 53 : 886-888, illus.

( 85 )

1958. TETRAZOLIUM CHLORIDE TO TEST LOBLOLLY PINE SEED VIABILITY. Forest Sci. 4:50-53, illus.

(86) Greene, S. W.

1935. EFFECT OF ANNUAL GRASS FIRES ON ORGANIC MATTER AND OTHER CONSTITUENTS OF VIRGIN LONGleaf PINE soils. Jour. Agr. Res. 50: 809-822.

(87) Greenham, C. G., and Cole, D. J.

1950. STUdiEs ON THE DETERMINATION OF DEAD OR DISEASED TISSUES. I. INVESTIGATIONS ON DEAd Plant tissues. Austral. Jour. Agr. Res. 1:103-117, illus.

(88) and DADAY, $\mathrm{H}$.

1957. ELECTRICAL DETERMINATION OF COLD HARDINESS IN Trifolium repens L. AND Medicago sativa L. Nature 180 (4585):541-543.

(89) Gruschow, G. F.

1952. EFFECT OF WINTER BURNING ON GROWTH OF SLASH PINE IN THE FLATWOODS. Jour. Forestry $50: 515-517$, illus.

(90) Hare, RoBert C.

1960. DETECTING DEAD CAMBIUM With A MOISTURE METER. Jour. Forestry 58:815-817, illus.

(91)

1961. RELATION OF BARK THICKNESS AND SPECIES to CAMbial fire resistance. U. S. Forest Serv. South. Forest Expt. Sta. Office Rpt., 16 pp., illus. [Unpublished.]

(92) Hartman, Arthur W.

1949. FIRE AS A TOOL IN SOUTHERN PINE. U.S. Dept. Agr. Yearbook 1949:517-527, illus.

(93) HedGCOCK, G. G.

1926. FIRE-SCAR DAMAGE IN WOODLANDS HEAVY. U. S. Dept. Agr. Yearbook 1926:363-364.

(94) HeilbrunN, L. V.

1924. THE COLLOIDAL CHEMISTRY OF PROTOPLASM. IV. THE HEAT COAGULATION OF PROTOPLASM. Amer. Jour. Physiol. 69:190-199, illus.
(95) Hepting, George H.

1935. DECAY FOLLOWING FIRE IN YOUNG MISSISSiPPi delta hardwoods. U.S. Dept. Agr. Tech. Bul. 494, 32 pp., illus.

(96)

1945. RESERVE FOOD STORAGE IN SHORTLEAF PINE in Relation to little-leaf disease. Phytopath. $35: 106-119$, illus.

(97) and Blaisdell, Dorothy J.

1936. A PROTECTIVE ZONE IN RED GUM FIRE SCARS. Phytopath. 26:62-67, illus.

(98) and Chapman, A. D.

1938. LOSSES FROM HEART ROT IN TWO SHORTLEAF AND LOBLOLLY PINE STANDS. Jour. Forestry 36:1193-1201.

(99) and HedGCoCK, G. G.

1937. DECAY IN MERCHANTABLE OAK, YELLOW-POPLAR, AND BASSWOOD IN THE APPALACHIAN REgION. U.S. Dept. Agr. Tech. Bul. 570, 29 pp., illus.

(100) HERMAN, F. R.

1950. SURVIVAL OF FIRE-DAMAGED PONDEROSA PINE; A PROGRESS REPORT. U.S. Forest Serv. Southwest. Forest and Range Expt. Sta. Res. Note 119,3 pp.

(101) Heyward, Frank D.

1934. COMMENTS ON THE EFFECT OF FIRE ON FEEDING ROOTS OF PINE. Naval Stores Rev. $44(19): 4$.

( 102$)$

1936. SOIL CHANGES ASSOCIATED WITH FOREST FIRES IN THE LONGLEAF PINE REGION OF THE south. Amer. Soil Survey Assoc. Bul. $17: 41-42$.

(103)

1937. THE EFFECT OF FREQUENT FIRES ON PROFILE DEVELOPMENT OF LONGLEAF PINE FOREST soils. Jour. Forestry $35: 23-27$, illus.

(104)

1938. SOIL TEMPERATURES DURING FOREST FIRES IN THE LONGLEAF PINE REgION, Jour, Forestry $36: 478-491$, illus.

(105)

1939. SOME MOISTURE RELATIONS OF SOILS FROM BURNED AND UNBURNED LONGLEAF PINE FORESTS. Soil Sci. $47: 313-324$, illus.

(106) and BARnette, R. M.

1934. EFFECT OF FREQUENT FIRES ON CHEMICAL COMPOSITION OF FOREST SOILS IN THE LONGleaf pine region. Fla. Agr. Expt. Sta. Bul. 265, 39 pp., illus.

(107) and Tissot, A. N.

1936. SOME CHANGES IN THE SOIL FAUNA ASSOCIATED WITH FOREST FIRES IN THE LONGLEAF PINE REGION. Ecol. 17:659-666, illus. 
(108) Highkin, H. R.

1957. THE RELATIONSHIP BETWEEN TEMPERATURE RESISTANCE AND PURINE AND PYRIMIDINE COMiposition IN PEAS. Plant Physiol. Suppl. 32:1. (Abstract.)

( 109 )

1959. EFFECT OF VERNALIZATION ON HEAT RESISTANCE IN TWO VARIETIES OF PEAS. Plant Physiol. 34:643-644.

(110) Hodgkins, E. J.

1958. EFFECTS OF FIRE ON UNDERGROWTH VEGETATION IN UPLAND SOUTHERN PINE FORESTS. Ecol. $39: 38-46$, illus.

(111) Hope, A. B., and Robertson, R. N.

1953. BIOELECTRIC EXPERIMENTS AND THE PROPERTIES OF PLANT PROTOPLASM. Austral. Jour. Sci. $15: 197-203$, illus.

(112) HOPKINS, C. Y.

1936. THERMAL DEATH POINT OF CERTAIN WEED SEEDS. Canad. Jour. Res. 14:178-183, illus.

(113) Jameson, Donald A.

1961. HEAT AND DESICCATION RESISTANCE OF IMPORTANT TREES AND GRASSES OF THE PINYONJUNIPER TYPE. Bot. Gaz. 122: 174-179, illus.

(114) Jemison, G. M.

1943. EFFECT OF SINGLE FIRES ON THE DIAMETER GROWTH OF SHORTLEAF PINE IN THE SOUTHERN APPAlachians. Jour. Forestry 41: 574-576.

( 115$)$

1944. THE EFFECT OF BASAL WOUNDING BY FOREST FIRES ON THE DIAMETER GROWTH OF SOME SOUTHERN APPALACHIAN HARDWOODS. Duke Univ. School Forestry Bul. 9, 63 pp., illus.

(116) Johnson, J.C.

1945. THERMISTOR TECHNICS. Electronic Indus. $4: 74-77$, illus.

(117) Julander, O.

1945. DROUGHT RESISTANCE IN RANGE AND PASTURE Grasses. Plant Physiol. 20:573-599, illus.

(118) Kessler, B.

1959. NUCLEIC ACIDS AS FACTORS IN DROUGHT RESISTANCE OF PLANTS. IX Internatl. Bot. Cong. Proc. II : 190.

(119) Konis, E.

1949. THE RESISTANCE OF MAQUIS PLANTS TO SUPRAMAXIMAL TEMPERATURES. Ecol. 30 : 425-429.

(120) Kurtz, EdwiN B., JR.

1958. CHEMICAL BASIS FOR ADAPTATION IN PLANTS. Science 128:1115-1117.

\section{(121) Lachmund, H. G.}

1921. SOME PHASES IN THE FORMATION OF FIRE SCARS. Jour. Forestry $19: 638-640$.
(122)

1923. BOLE INJURY IN FOREST FIRES. Jour. Forestry $21: 723-731$, illus.

(123) Langridge, J., and Griffing, B.

1959. A STUDY OF HIGH TEMPERATURE LESIONS IN Arabidopsis thaliana. Austral. Jour. Biol. Sci. 12:117-135.

(124) LeBarron, Russell K.

1957. Silvicultural Possibilities of Fire in NORTHEASTERN WASHINGTON. Jour. Forestry $55: 627-630$.

(125) LeMON, P. C.

1949. SUCCESSIONAL RESPONSES OF HERBS IN THE LONGLEAF-SLASH PINE FORESTS AFTER FIRE. Ecol. $30: 135-145$.

(126) LevitT, J.

1951. Frost, DROUGHT AND hEAT RESISTANCE. Ann. Rev. Plant Physiol. 2:245-268.

(127) Lindenmuth, A. W., Jr., and Byram, GEORGE M.

1948. HEADFIRES ARE COOLER NEAR THE GROUND THAN BACKFIRES. U. S. Forest Serv. Fire Control Notes 9(4): 8-9, illus.

(128) LitTle, S.

1953. PRESCRIBED BURNING AS A TOOL OF FOREST MANAGEMENT IN THE NORTHEASTERN STATES. Jour. Forestry 51:496-500.

(129) Allen, J. P., and Moore, E. B.

1948. CONTROLLED BURNING AS A DUAL-PURPOSE TOOL OF FOREST MANAGEMENT IN NEW JERSEY'S PINE REgION. Jour. Forestry 46 : 810-819, íllus.

(130) and Moore, E. B.

1949. THE ECOLOGICAL ROLE OF PRESCRIBED BURNS IN THE PINE-OAK FORESTS OF SOUTHERN NEW JERSEY. Ecol. 30:223-233, illus.

(131) and Somes, H. A.

1956. BUDS ENABLE PITCH AND SHORTLEAF PINES TO recover from inJUry. U. S. Forest Serv. Northeast. Forest Expt. Sta. Sta. Paper 81, $14 \mathrm{pp}$.

(132) and Somes, H. A.

1960. SPROUTING OF LOBLOLLY PINE. Jour. Forestry $58: 195-197$, illus.

(133) LoNghuRst, William M.

1956. STUMP SPROUTING OF OAKS IN RESPONSE TO seasonal cutting. Jour. Range Mangt. 9:194-196.

(134) LoRenz, Ralph W.

1939. HIGH TEMPERATURE TOLERANCE OF FOREST Trees. Univ. Minn. Agr. Expt. Sta. Tech. Bul. 141, 25 pp., illus.

(135) Lorenzen, C., Jr.

1949. THE THERMOCOUPLE IN AGRICULTURAL RESEARCH. Agr. Engin. 30:275-279, illus. 
(136) LotTi, Thomas.

1956. ELIMINATING UNDERSTORY HARDWOODS WITH SUMMER PRESCRIBED FIRES IN COASTAL PLAIN LOBLOLLY PINE STANDS. Jour. Forestry 54:191-192, illus.

(137)

1960. THE USE OF FIRE IN THE MANAGEMENT OF coastal plain loblolly pine. Soc. Amer. Foresters Proc. 1959: 18-20, illus.

(138) LuTz, H. J.

1956. ECOLOGICAL EFFECTS OF FOREST FIRES IN the interior of alaska. U. S. Dept. Agr. Tech. Bul. 1133, 121 pp., illus.

(139)

1960. FIRE AS AN ECOLOGICAL FACTOR IN THE BOREAL FOREST OF ALASKA. Jour. Forestry 58:454-460, illus.

(140) LUYET, B. J.

1932. VARIATION OF THE ELECTRICAL RESISTANCE OF PLANT TISSUES FOR ALTERNATING CURRENTS OF DIFFERENT FREQUENCIES DURING DEATH. Jour. Gen. Physiol. 15:283-287, illus.

(141) and Gehenio, P. M.

1936. ULTRAVIOLET ABSORPTION IN LIVING AND DEAD CELLS. Biodynamica 1(11):1-8, illus.

(142) and Gehenio, P.M.

1936. CELLULAR PIGMENTS VERSUS VITAL STAINS IN THE SPECTRAL ABSORPTION OF LIVING AND DEAD MATTER. Biodynamica 1(24):1-4, illus.

(143) LYNCH, D. W.

1959. EFFECTS OF A WILDFIRE ON MORTALITY AND GROWTH OF YOUNG PONDEROSA PINE TREES. U. S. Forest Serv. Intermountain Forest and Range Expt. Sta. Res. Note 66, 8 pp., illus.

(144) MacDougal, D. T.

1922. How Plants ENdure heAt ANd COLD. Gard. Mag. and Homebuilder 36:152-154, illus.

(145) MACKINNEY, A. L.

1934. SOME FACTORS AFFECTING THE BARK THICKNESS OF SECOND-GROWTH LONGLEAF PINE. Jour. Forestry 32:470-474.

(146)

1934. SOME EFFECTS OF THREE ANNUAL FIRES ON GROWTH OF LONGLEAF PINE. Jour. Forestry $32: 879-881$.

(147) MacLean, J. D.

1940. RELATION OF WOOD DENSITY TO RATE OF TEMPERATURE CHANGE IN WOOD IN DIFFERENT HEATING MEDIUMS. Amer. Wood Preservers' Assoc. Proc. 36:220-248, illus.

(148) McClure, T. T.

1960. ChLOROGENIC ACID ACCUMULATION AND WOUND HEALING IN SWEET POTATO ROOTS. Amer. Jour. Bot. 47:277-280.
(149) McCulley, Robert D.

1950. MANAGEMENT OF NATURAL SLASH PINE STANDS IN THE FLATWOODS OF SOUTH GEORGIA AND NORTH FlORIDA. U.S. Dept. Agr. Cir. 845, 57 pp., illus.

(150) Maguire, William P.

1955. RADIATION, SURFACE TEMPERATURE AND SEedling survival. Forest Sci, 1:277-285, illus.

(151) ManN, W.F., Jr., and Gunter, E. R.

1960. PREDICTING THE FATE OF FIRE-DAMAgED PINES. Forests and People 10(1):26-27, 43, illus.

(152) Meyer, B. S., and Anderson, D. B. 1939. PLANT PHYSIOLOGY. 696 pp., illus. N. Y.

(153) Mrtchell, H. K., and Houlahan, M. B.

1946. NEUROSPORA. IV. A TEMPERATURE-SENSItive riboflavinless mutant. Amer. Jour. Bot. $33: 31-35$.

(154) Monselise, S. P.

1953. viability Tests With Citrus seeds. Palestine Jour. Bot., Rehovot Ser. 8:152-157.

(155) MORRIS, H. J.

1958. TEST PAPER FOR DETECTING PEROXIDASE. Agr. and Food Chem. 6:383-384.

(156) Morris, W. G., and Mowat, E. L.

1958. SOME EFFECTS OF THINNING A PONDEROSA PINE THICKET WITH A PRESCRIBED FIRE. Jour. Forestry $56: 203-209$, illus.

(157) NAKAMURA, S.

1959. EXPERIMENTS OF FIRE RESISTANCE OF COMMON TREES AND SHRUBS IN JAPAN. Shimane Agr. Col. Bul. $7: 154-164$.

(158) NegruckiJ, S. F.

1959. [RESUlts OF TESTING POLOZENCEV'S AND HANISLAMOV'S INSTRUMENTS FOR DIAGNOSING THE CONDITION OF LIVING TREES.] (RUSsian.) Bot. Z. 44( 7 ):959-962. See Forestry Abs. 21 (2):1911. 1960.

(159) Nelson, R. M.

1952. OBSERVATIONS ON HEAT TOLERANCE OF SOUTHERN PINE NEEdLES. U. S. Forest Serv. Southeast. Forest Expt. Sta. Sta. Paper 14, 66 pp., illus.

(160) and BRUCE, DAVID.

1958. FOREST FIRE RESEARCH NEEDS IN THE SOUTH. Jour. Forestry 56:399-403.

(161) and Sims, I. H.

1934. A METHOD FOR MEASURING EXPERIMENTAL FOREST FIRE TEM PERATURES. Jour. Forestry $32: 488-490$.

(162) Sims, I. H., and AbELL, M. S.

1933. BASAL FIRE WOUNDS ON SOME SOUTHERN APPALACHIAN HARDWOODS. Jour. Forestry $31: 829-837$, illus. 
(163) NORDIN, V.J

1958. BASAL FIRE SCARS AND THE OCCURRENCE OF DECAY IN LODGEPOLE PINE. Forestry Chron. $34: 257-265$, illus.

(164) Oland, K.

1960. NITROGEN FEEDING OF APPLE TREES BY POSTHARVEST UREA SPRAYS. Nature 185(4716): 857.

(165) Osterhout, W. J. V.

1922. INJURY, RECOVERY AND DEATH IN RELATION TO CONDUCTIVITY AND PERMEABILITY. 259 pp., illus. Philadelphia.

(166) PARKFR, JohnSON.

1953. SOME APPLICATIONS AND LIMITATIONS OF TETRAZOLIUM CHLORIDE. Sci. 118:77-79, illus.

( 167 )

1955. EFFEcts of Vital STAINING in Pinus ponderosa. Plant Physiol. Suppl. 30:x (Abs.)

(168)

1956. DROUGHT RESISTANCE IN WOODY PLANTS. Bot. Rev, 22:241-289.

(169) Parmelee, George V., and Huebscher, RICHARD G.

1946. THE SHIELDING OF THERMOCOUPLES FROM THE EFfects of Radiation. Heating, Piping and Air Cond., Feb., 144-146, illus.

(170) Paulsell, Lee K.

1957. EFFECTS OF BURNING ON OZARK HARDWOOD timberlands. Mo. Agr. Expt. Sta. Res. Bul. 640, 24 pp., illus.

(171) Petinov, N. S., and Molotkovsky, Y. G.

1957. PROTECTIVE REACTIONS IN HEAT-RESISTANT PLANTS INDUCED BY HIGH TEMPERATURES. Fiziol. Rastenii (Transl.) 4930:221-228.

(172) Preston, J.F., and Phillips, F.J.

1911. SEASONAL VARIATION IN THE FOOD RESERVES OF TREES. Forestry Quart. 9:232-243.

(173) QUiCK, C. R.

1959. CEANOTHUS SEEDS AND SEEDLINGS ON BURNS. Madrono $15: 79-81$.

(174) Quiggle, D., Tonberg, C. O., and Fenske, M. R.

1937. RELIABILITY OF COMMON TYPES OF THFRMIOCouples. Ind. Engin. Chem. 29:827-830, illus.

(175) Reynolds, E. S.

1939. TREE TEMPERATURES AND THERMOSTASY. Mo. Bot. Gard. Ann. 26:165-255, illus.

(176) Roberts, C. C., and Vogelsang, C. A.

1949. SOME BASIC CONCEPTS OF THERMOELECTRIC PYROMETRY. Instrumentation 4(1):25-27, illus.
(177) RoBERTS, L.W.

1951. SURVEY OF FACTORS RESPONSIBLE FOR REDUCTION OF 2, 3, 5- TRIPHENYLTETRAZOLIUM CHLORIDE IN PLANT MERISTEMS. Sci. 113: $692-693$.

(178) RoEsER, J., JR.

1932. TRANSPIRATION CAPACITY OF CONIFEROUS SEEDLINGS AND THE PROBLEM OF HEAT INJURY. Jour. Forestry 30:381-395, illus.

(179) St.George, R. A., and Beal, J. A.

1927. STUdies ON THE SOUTHERN PINE BEETLE. U. S. Forest Serv. Appalachian Forest Expt. Sta. Prog. Rpt., 37 pp., illus. [Unpublished.]

(180) Sampson, Arthur W.

1944. PLANT SUCCESSION ON BURNED CHAPARRAL LANDS IN NORThERN CALlFornia. Calif. Agr. Expt. Sta. Bul. 685, 144 pp., illus.

(181) Scott, V.H., and Burgy, R. H.

1956. EFFECTS OF HEAT AND BRUSH BURNING ON THE PHYSICAL PROPERTIES OF CERTAIN UPLAND SOILS THAT INFLUENCE INFILTRATION. Soil Sci. 82:63-70, illus.

(182) Shcherbakov, 1. N.

1956. [USE OF A SEMI-CONDUCTING ELECTRIC THERMOMETER FOR TEMPERATURE MEASUREMENTS IN TREE TISSUE.] (Russian.) Referat. Zhur., Biol. 1956:71653. (Transl.)

(183) Shirley, H. C.

1936. LETHAL HIGH TEMPERATURES FOR CONIFERS, AND THE COOLING EFFECT OF TRANSPIRATION. Jour. Agr. Res. $53: 239-258$, illus.

(184) Siggers, P. V.

1934. OBSERVATIONS ON THE INFLUENCE OF FIRE ON THE BROWN-SPOT NEEDLE BLIGHT OF LONGLEAF PINE SEEDLINGS. Jour. Forestry 32 : 556-562, illus.

(185)

1949. FIRE AND THE SOUTHERN FUSIFORM RUST. Forest Farmer 8(5): 16, 21, illus.

(186) SoE, K.

1959. ANATOMICAL STUDIES OF BARK REGENERATION FOLLOWING SCORING. Jour. Arnold Arboretum 40:260-267, illus.

(187) Southern Forest Experiment Station.

1959. 1958 AT THE SOUTHERN FOREST EXPERIMENT Station. U. S. Forest Serv. South. Forest Expt. Sta. 1958 Ann. Rpt., 72 pp., illus.

(188)

1960. 1959 AT THE SOUTHERN FOREST EXPERIMENT Station. U. S. Forest Serv. South. Forest Expt. Sta. 1959 Ann. Rpt., 77 pp., illus.

(189) Spalt, Karl, and Reifsnyder, W. E.

1961. BARK CHARACTERISTICS AND FIRE RESISTANCE: A Literature Survey. U. S. Forest Serv. South. Forest Expt. Sta. Occas. Paper [In press.]

(190) Starker, T. J.

1934. FIRE RESISTANCE IN THE FOREST. Jour. Forestry $32: 462-467$. 
(191) Stickel, Paul W.

1934. FOREST FIRE DAMIAGE STUDIES IN THE NORTHEAST. I. BARK-BEETLES AND FIRE DAMAGED HARDWOODS. Jour. Forestry 32:701703 .

(192)

1935. FOREST FIRE DAMAGE STUDIES IN THE NORTHEAST. II. FIRST-YEAR MORTALITY IN BURNEDOVER OAK STANDS. Jour. Forestry 33: 595598.

( 193 )

1940. THE BASAL-WOUNDING OF TREES BY FIRE-A Progress report. U. S. Forest Serv. Northeast. Forest Expt. Sta., 14 pp., illus.

(194)

1940. THE EFFECT OF BASAL-WOUNDING BY FIRE ON TREES IN THE NORThEAST. U. S. Forest Serv. Northeast. Forest Expt. Sta. Tech. Note $30,2 \mathrm{pp}$

(195)

1941. ON THE RELATION BETWEEN BARK CHARACTER AND RESistance to fire. U. S. Forest Serv. Northeast. Forest Expt. Sta. Tech. Note $39,2 \mathrm{pp}$.

(196) Stoddard, H. L.

1936. RELATION OF BURNING TO TIMBER AND WILDLIFE. North Amer. Wildlife Conf. Proc. $1: 399-403$.

(197) Stone, E. L., JR.

1940. PROGRESS REPORT ON THE EFFECT OF FIRE ON THE RADIAL GROWTH OF LONGLEAF PINE. U. S. Forest Serv. South. Forest Expt. Sta., 26 pp., illus. [Unpublished.]

(198)

1944. EFFECT OF FIRE ON TAPER OF LONGLEAF PINE. Jour. Forestry $42: 607$.

(199) Storey, T. G., and Merkel, E. P.

1960. MORTALITY IN A LONGLEAF-SLASH PINE STAND FOLLOWING A WINTER WILDFIRE. Jour. Forestry 58:206-210, illus.

(200) Tarrant, Robert F.

1954. EFFECT OF SLASH BURNING ON SOIL $\mathrm{pH}$. U.S. Forest Serv. Pacific Northwest Forest and Range Expt. Sta. Res. Note 102, 5 pp.

(201)

1956. CHANGES IN SOME PHYSICAL SOIL PROPERTIES AFTER A PRESCRIBED BURN IN YOUNG PONDEROSA PINE. Jour. Forestry 54:439-441, illus.

(202) TeEsdale, L. V.

1955. THERMAL INSULATION MADE OF WOOD-BASE Materials. U. S. Forest Serv. Forest Prod. Lab. Rpt. 1740, 46 pp., illus. (Rev. 1958.)

(203) TERRY, R. A.

1951. HOW TO CONSERVE THERMOCOUPLE EXTENSION WIRE. Instrumentation $5(5): 24$, illus.
(204) Thames, J.L.

1959. THE EFFECT OF SOME ENVIRONMENTAL FACTORS ON TRANSPIRATION OF LOBLOLLY PINE. U. S. Forest Serv. South. Forest Expt. Sta. Prog. Rpt.

(205) Thimann, K. V., and Kaufman, David.

1958. CYTOPLASMIC STREAMING IN THE CAMBIUM of White pine. The Physiology of Forest Trees, pp. 479-492, illus. N. Y.

(206) TOOLE, E. Richard.

1959 DECAY AFTER FIRE INJURY TO SOUTHERN BOtTOM-LAND haRDWOods. U. S. Dept. Agr. Tech. Bul. 1189, 25 pp., illus.

(207) and McKNIGHT, J.S.

1956. FIRE EFFECTS IN SOUTHERN HARDWOODS. U. S. Forest Serv. Fire Control Notes $17(3): 1-4$, illus.

(208) TWEeddale, J. E.

1945. THERMISTORS. Western Electric Oscillator $2: 3-5,34-37$, illus.

(209) Uggla, Evald.

1957. [TEMPERATURES DURING CONTROLLED BURNING. THE EFFECT OF THE FIRE ON THE VEGETATION AND THE HUMUS COVER.] (Swedish.) Norrlands Skogsvardsfor. Tidskr. 1957 (4) :443-500.

(210)

1958. ECOLOGICAL EFFECTS OF FIRE ON NORTH SWEDISH FORESTS. Almqvist and Wiksells, Upsalla, $18 \mathrm{pp}$.

(211) U. S. Dept. Commerce.

1955. TEMPERATURE MEASUREMENTS-A LIST OF Publications. Natl. Bur. Standards Publ. LP 32.

(212) U. S. Forest Service.

1956. GLOSSARY OF TERMS USED IN FOREST FIRE Control. U.S. Dept. Agr. Agr. Handb. $104,24 \mathrm{pp}$.

( 213 ) Ursic, S. J.

1961. LETHAL ROOT TEMPERATURE OF 1-0 LOBLOLLY PINE SEEDLINGS. U. S. Forest Serv. Tree Planters' Notes. (In press.)

(214) VEHRENCAMP, JOHN E.

1956. AN INVESTIGATION OF FIRE BEHAVIOUR IN A NATURAL ATMOSPHERIC ENVIRONMENT. Univ. Calif. Dept. Engin. Tech. Rpt. 1, 85 pp., illus.

(215) VERE, D. W.

1958. HEAT TRANSFER MEASUREMENT IN LIVING SkIN. Jour. Physiol. (London) 140:359380 , illus.

(216) Verrall, Arthur F.

1936. THE Dissemination of Septoria acicola AND THE EFFECT OF GRASS FIRES ON IT IN PINE NEEDLES. Phytopath. 26: 1021-1024. 
(217) Verrall. ArthUR $F$

1938. THE PROBABLE MECHANISM OF THE PROTECTIVE ACTION OF RESIN IN FIRE WOUNDS ON RED PINE. Jour. Forestry 36:1231-1233, illus.

(218) Vlamis, J., Biswell, H. H., and Schultz, A. M.

1955. EFFECTS OF PRESCRIBED BURNING ON SOIL FERTILITY IN SECOND GROWTH PONDEROSA PINE. Jour. Forestry 53:905-909, illus.

(219) Vogelsang, C. A., and Sine, J. D.

1953. PYROMETRIC MIDGETS. Instrumentation $6(4): 33-36$, illus.

(220) WAgener, Willis W.

1955. PRELIMINARY GUIDELINES FOR ESTIMATING THE SURVIVAL OF FIRE-DAMAGED TREES. U. S. Forest Serv. Calif. Forest and Range Expt. Sta. Forest Res. Note 98, 9 pp.

(221) Wahlenberg, W. G.

1935. EFFECT OF FIRE AND GRAZING ON SOIL PROPERTIES AND THE NATURAL REPRODUCTION OF LONGLEAF PINE. Jour. Forestry $33: 331-337$.

(222)

1946. LONGLEaf Pine. 429 pp., illus. Wash., D. C.

(223) Greene, S. W., and Reed, H. R.

1939. EFFECTS OF FIRE AND CATTLE GRAZING ON LONGLEAF PINE LANDS AS STUDIED AT MCNEILL, MISSISSIPPI. U. S. Dept. Agr. Tech. Bul. 683,52 pp., illus.

(224) Wakeley, P. C.

1954. Planting the Southern Pines. U. S. Forest Serv. Agr. Monog. 18, 233 pp., illus.

(225) — and Muntz, H. H.

1947. EFFECT OF PRESCRIBED BURNING ON HEIGHT GROWTH OF LONGLEAF PINE. Jour. Forestry $45: 503-508$, illus.

(226) WALKER, N.A.

1958. ION PERMEABILITY OF THE PLASMALEMMA OF THE PLANT CELL. Nature 181(4618): 1288-1289.

(227) WAREING, P. F.

1958. THE PHYSIOLOGY OF CAMBIAL ACTIVITY. Inst. Wood Sci. Jour. 1:34-42.

(228) Watson, A. N.

1933. PRELIMINARY STUDY ON THE RELATION BETWEEN THERMAL EMISSIVITY AND PLANT temperatures. Ohio Jour. Sci. 33:435450 .

(229)

1934. FURTHER STUDIES ON THE RELATION BETWEEN THERMAL EMISSIVITY AND PLANT TEMPERATures. Amer. Jour. Bot. 21:605-609.
(230) Weaver, Harold.

1943. FIRE AS AN ECOLOGICAL AND SILVICULTURAL FACTOR IN THE PONDEROSA PINE REGION OF THE PACIFIC SLOPE. Jour. Forestry $41: 7-15$, illus.

(231)

1947. FIRE-NATURE'S THINNING AGENT IN PONDEROSA PINE STANDS. Jour. Forestry 45:437444 , illus.

(232)

1955. FIRE AS AN ENEMY, FRIEND, AND TOOL IN FOREST MANAGEMENT. Jour. Forestry 53: 499-504, illus.

(233)

1957. EFFECTS OF PRESCRIBED BURNING IN SECOND GROWTH PONDEROSA PINE. Jour. Forestry $55: 823-826$, illus.

(234)

1959. ECOLOGICAL CHANGES IN THE PONDEROSA PINE FORESTS OF THE WARM SPRINGS INDIAN RESERVATION IN OREGON. Jour. Forestry $57: 15-20$, illus.

(235) Weddell, D. J., and WARE, L. M.

1936. THE EFFECT OF FIRES OF DIFFERENT FREQUENCIES ON THE SURVIVAL OF DIFFERENT SPECiEs of Pine. Ala. Agr. Expt. Sta. 47th. Ann. Rpt., pp. 28-29.

(236) Whitaker, D. M.

1929. CONSTRUCTION OF MICRO-THERMOCOUPLES. Sci. $70: 263-266$, illus.

(237) WOODS, FRANK W.

1955. CONTROL OF WOODY WEEDS, SOME PHYSIological aspects. U. S. Forest Serv. South. Forest Expt. Sta. Occas. Paper 143, $50 \mathrm{pp}$

(238) Harris, H. C., and Caldwell, R. E. 1959. MONTHLY VARIATIONS OF CARBOHYDRATES AND NITROGEN IN ROOTS OF SANDHILL OAKS AND WIREgrass. Ecol. 40:292-295, illus.

(239) Wright, Ernest, and Tarrant, Robert F.

1957. MICROBIOLOGICAL SOIL PROPERTIES AFTER LOGGING AND SLASH BURNING. U.S. Forest Serv. Pacific Northwest Forest and Range Expt. Sta. Res. Note 57, 5 pp.

(240) and Tarrant, Robert F.

1958. OCCURRENCE OF MYCORRHIZAE AFTER LOGGING AND SLASH BURNING IN THE DOUGLASFIR FOREST TYPE. U.S. Forest Serv. Pacific Northwest Forest and Range Expt. Sta. Res. Note 160, 7 pp., illus.

(241) ZDRAJKOVSKIJ, D. I.

1958. [DETERMINATION OF THE RESISTANCE OF PINE IN FOCI OF Fomes annosus INFECTION.] (In Russian.) Lesn. Hoz. 11(12):40-42. Forestry Abs. 21(2):1912. 1960. 

